
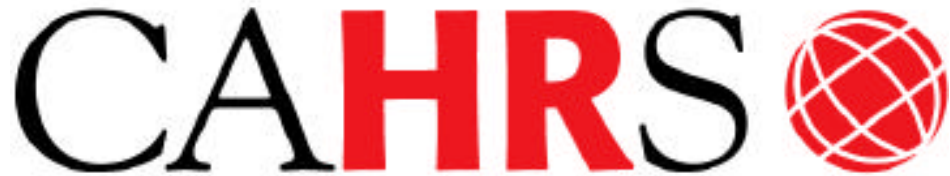

Center for Advanced Human Resource Studies
CAHRS / Cornell University 187 Ives Hall

Ithaca, NY 14853-3901 USA

Tel. $607255-9358$

www.ilr.cornell.edu/CAHRS/

Working Paper Serles

\title{
Gainsharing: A Critical Review and a Future Research Agenda
}

\section{Theresa M. Welbourne \\ Luis R. Gomez Mejia}

Working Paper 9 5-10 


\title{
Gainsharing: \\ A Critical Review and A Future Research Agenda
}

\author{
Theresa M. Welbourne \\ Center for Advanced Human Resource Studies \\ Cornell University \\ 393 Ives Hall \\ Ithaca, NY 14853-3901 \\ and \\ Luis R. Gomez Mejia \\ Department of Management \\ College of Business \\ Arizona State University \\ Tempe, AZ 85287-4006
}

Working Paper 95-10

$\underline{\text { www.ilr.cornell.edu/cahrs }}$

This paper has not undergone formal review or approval of the faculty of the ILR School. It is intended to make results of research, conferences, and projects available to others interested in human resource management in preliminary form to encourage discussion and suggestions. 


\begin{abstract}
This paper provides a critical review of the extensive literature on gainsharing. It examines the reasons for the fast growth in these programs in recent years and the major prototypes used in the past. Different theoretical formulations making predictions about the behavioral consequences and conditions mediating the success of these programs are discussed and the supporting empirical evidence is examined. The large number of a theoretical case studies and practitioner reports or gainsharing are also summarized and integrated. The article concludes with a suggested research agenda for the future.
\end{abstract}


Gainsharing has a long history that may be traced back to the 19th century (Welbourne \& Gomez-Mejia, 1988), yet not until recently has it played a major role as a pay-for-performance system across a broad spectrum of firms. Imberman (1993) reports that at least 2,000 firms are now using gainsharing, a dramatic increase over a decade ago. Markham, Scott \& Little (1992) found in a survey of 10,000 members of the Society for Human Resource Management (SHRM) that gainsharing has transcended its original roots in the manufacturing sector and it is currently used in all industries, including the public sector. A separate survey of SHRM members conducted by the Alexander Consulting Group (1992) showed that other than health care, gainsharing is mentioned by HR managers as the most important human resource topic in the 1990s, ahead of employee diversity, corporate culture, work redesign and other contemporary issues. A survey of Fortune 1,000 firms by Lawler and Cohen (1992) confirms this trend: $39 \%$ of these companies rely on some form of gainsharing program, a one-third increase over a similar survey conducted just three years earlier.

Gainsharing is not a single type of incentive program. Rather, it is an umbrella for a family of aggregate pay-for-performance approaches that link financial rewards for employees to improvements in the performance of the entire unit. Increasingly these plans are "custom designed" in each firm; in fact, almost one-half of the gainsharing plans now in existence are idiosyncratic to the company implementing it (Markham et al., 1992). However, these customized plans tend to be variants of three traditional types of gainsharing programs to be described in some detail later: Scanlon (with a strong reliance on employer involvement), Rucker (which is similar to Scanlon but utilizes a different calculation to distribute bonuses) and Improshare (with a greater emphasis on the financial bonus rather than on employee participation per se).

Regardless of the actual plan used, there are several reasons that may account for the growing popularity of gainsharing. First, an increasing number of firms are moving toward a team-based work design (e.g., Scarp, 1995). The basic concept of a job may be undergoing a fundamental change from a prescribed set of tasks and duties assigned to individual workers to a broad definition of expectations, including a person's ability to perform multiple tasks and be flexible to contribute to one or more work teams depending on need (Manz \& Sims, 1993). This new emphasis on flexibility and cooperative efforts is conducive to an aggregate incentive plan, such as gainsharing, that rewards employees for group outcomes (Gomez-Mejia \& Balkin, 1992J. While team based incentives may be used, their application is limited by the fact that teams are often transient, individuals belong to multiple teams, the performance of various teams is likely to be interdependent, and inter-team competition may be dysfunctional to the 
achievement of overall corporate goals. Gainsharing is particularly well suited to a team environment because rewards are linked to the performance of the entire unit which reflect the cumulative contribution of all teams (Welbourne, Balkin, \& Gomez-Mejia, in press).

A second reason for the increased use of gainsharing is dissatisfaction with other types of pay-for-performance systems. In particular, programs to reward individual performance (such as merit pay and bonuses) more often than not lead to disappointing results (e.g., Cumming, 1995; Mount, 1987; Pearce, Stevenson \& Perry, 1985). Many reasons have been advanced for this dissatisfaction, most notably the difficulty in untangling an individual's contribution from that of other employees (e.g., Ilgen \& Feldman, 1983; Liden \& Mitchell, 1983; Yammarino, Dubinsky \& Hartley, 1987); performance measurement problems or supervisory rating errors (e.g., Cardy \& Dobbins, 1993); lack of credibility because many non-performance factors (such as position in the salary range) enter into these decisions (Schwab \& Olson, 1988); and social disruption engendered by increased competition and disgruntled employees who feel that they deserve better (Pearce et al., 1985; Hughes, 1986). As firms scramble to find alternative mechanisms to reward performance, gainsharing is often adopted as a "lesser evil" or as a viable option with fewer negative side effects (Gomez-Mejia \& Balkin, 1992).

A third related reason for greater reliance on gainsharing is that these programs are easier to sell to top management. The out-of-pocket expenses for the firm are generally low since any payoffs accrued by workers are linked to future unit performance and any realized gains are distributed between employees and the firm. By definition, any compensation received by employees under this type of program is variable rather than fixed in nature so that the firm is not committed to a permanent resource allocation. Employees are made to partially carry the burden or risks of future performance uncertainty (Graham-Moore \& Ross, 1990).

Fourth, there is a long history of experience with gainsharing and firms can easily imitate these plans by copying or modifying gainsharing programs used by competitors. There is a large amount of literature documenting technical information on the various formulas employed by firms and other specific details on how these plans have been administered and implemented. As we will see later, literally hundreds of case studies have been conducted on gainsharing, and much of this information is in the public domain. As a whole the published materials speak highly of gainsharing, inducing other firms to join the bandwagon.

There are several consulting firms that specialize on gainsharing, and the popular business press often provides prescriptions or recipes on what it takes to launch a successful gainsharing program. At a public policy level, gainsharing has been endorsed by the White House Conference on Productivity, the General Accounting Office, and the President's Task 
Force on Industrial Competitiveness (Lawler, 1990). The Canadian government has also stimulated the growth of gainsharing programs as evidenced by the Royal Commission on the Economic Union and Development Project's recommendation that it be implemented on a national basis in an effort to improve productivity (Long, 1989).

Fifth, gainsharing programs offer substantial flexibility in the chosen formulas to determine the payoff and procedures for distributing gains. For instance, the payoff criteria used may involve such a widely diverse set of factors as profitability, labor costs, material savings, meeting deadlines, percent rejects, safety record and customer satisfaction (Masternak, 1993). Many firms are experimenting with differential distribution of bonuses using such factors as team performance, seniority, job classification, cooperation, and special achievements (Harrington \& Harrington, 1995; Owens, 1991). The actual procedures to distribute awards are also varied; these may involve supervisor's ratings, employee-management committees, cross-functional management teams and peer appraisals (Peck, 1991 ${ }_{\mathrm{a}, \mathrm{b}}$ ). This type of creative experimentation with gainsharing programs allows organizations to circumvent some of the traditional criticisms of the low motivational impact of aggregate incentives, namely that "free riding" and a "weak line of vision" between behavior and outcome reduce their reinforcement value.

Lastly, some forms of gainsharing provide an operational mechanism to implement participative management. The desirability of employee involvement has its roots in the human relations movement as exemplified in the Hawthorne experiments of the 1920's. Despite much lip-service to this concept over the years, participative management has been more of an academic than a practical reality (Gomez-Mejia, Balkin, \& Cardy, 1995). Gainsharing represents a major exception. Many gainsharing plans contain a committee structure to elicit and evaluate employee suggestions thereby providing an efficient channel to promote employee involvement and convert it into an action plan.

The purpose of this article is to review the literature on gainsharing and elaborate a future research agenda. Several earlier reviews have been conducted but most of these are based on a select number of case studies (Bullock \& Lawler, 1984; revisited in a later paper by Bullock \& Tubbs, 1990), focus on a historical narrative of these plans (Gowen, 1990), or tend to be applied in nature (Graham-Moore \& Ross, 1990; Welbourne \& Gomez-Mejia, 1988). The present manuscript reviews a total of 162 publications on gainsharing encompassing six decades. The information was gathered from a variety of sources, including computer data bases (e.g., ABI-Inform, Infotrac, Psych abstracts, ERIC, and ECONLIT) in addition to a thorough examination of the major journals in the field. Particular emphasis is given to more 
recent work, most of it less than ten years old and not yet integrated. This contemporary literature has a stronger theoretical flavor than earlier publications which as a whole were largely descriptive and prescriptive.

We divide the review into four sections. First, we provide a brief description of gainsharing prototypes; most programs include features of these plans. While this material is already familiar to many readers, it provides a context for the subsequent literature review. Second, we examine several theoretical perspectives that have recently been used as explanatory frameworks to assess the antecedents and consequences of gainsharing outcomes. Empirical evidence, if any, is also presented in light of hypothesized relationships. Third, we examine the vast atheoretical literature on gainsharing, most of it consisting of case studies, exploratory research, descriptive surveys, and other practitioner publications. This body of information, when coupled with the theory based research reviewed in the preceding section, provides a more comprehensive assessment of the impact of gainsharing and conditions favoring its success. The article concludes with a discussion section that addresses research gaps identified in the literature review and that raises interesting questions on gainsharing that are important both from a scholarly and applied perspective.

\section{GAINSHARING PROGRAMS}

Gainsharing generally consist of two components: A financial formula that serves as the basis for the bonus system and some type of formal employee involvement program. As noted earlier, many firms are developing their own customized gainsharing plans. These are usually a variant of one of the gainsharing programs described next: Scanlon, Rucker, and Improshare.

\section{Gainsharing Formulas}

The Scanlon plan utilizes a fairly simple formula, which is considered to be one of the advantages of this program because it is easily calculated, administered, and understood by employees. The concept behind the Scanlon formula is that increases in labor productivity should be shared with employees. Therefore, the formula first seeks to secure a stable and historical ratio representing productivity, which is usually measured as the ratio of labor costs to either revenues, net sales, or sales value of production. The simple calculation is often referred to as the "single ratio"; the formula may also be modified by including other costs such as materials, overhead, rejects and the like. Gains in productivity that result from either increases in production or cost savings are shared with the workers when the observed ratio is less than the historical ratio (Doyle, 1983).

The ratio used by organizations that implement the Rucker plan is slightly different. According to Metzger (1985) "the Rucker Plan pays a bonus when a value added gain is 
realized. Value added is defined as sales minus raw materials and services procured outside the company" (p. 11). The Rucker plan is similar to the single ratio Scanlon plan in that the numerator is the same (labor costs); however, the Rucker plan attempts to account for the increased value of sales (due to the market factors, inflation, etc., not attributed to efforts made by employees) and the costs of materials and supplies (also due to factors in the external environment, unrelated to workers' efforts) by including both of these factors in the denominator. Therefore, inflationary and market effects theoretically are cancelled out. The ratio used under Rucker is as follows:

Labor Costs/Value Added (Sales - Raw Materials)

According to the formula above, when labor costs (numerator) as a percentage of the value of production or sales (denominator) decrease, then a bonus pool is established. GrahamMoore and Ross (1990) provide an example of a single ratio monthly report that shows the allowed payroll costs (based on an analysis of the historical data) to be $20 \%$. Actual payroll costs for the period, based on a value of production of $\$ 1,200,000$, are $\$ 210,000$ (17.5\%). The allowed payroll cost (based on the established ratio of $20 \%$ and production valued at $\$ 1,200,000)$ is $\$ 240,000$. Therefore, the savings for this period are $\$ 30,000(240,000-210,000)$. This could also be calculated using the percentage savings of $\{20 \%-17.5 \%=2.5 \%$ $(1,200,000)\}=\$ 30,000$.

After the bonus pool is established (whether through the Scanlon or Rucker formula), it is distributed between employees and the organization. The employee share of the bonus pool typically range between $25 \%$ and $75 \%$, and bonus payments can be paid on weekly, monthly, or quarterly schedules. A percentage of the employee bonus is normally retained in a reserve fund, which is then distributed at the end of the year in the event that a positive balance remains. The bonus pool is most commonly distributed to employees participating in the plan as a percentage of their wages; in a few cases organizations have opted to split the bonus pool equally among all employees who participate in the program.

Improshare (improved production through sharing) focuses on sharing physical productivity gains with employees. Standard hours are calculated for the manufacturing of each product, and a bonus is earned when the hours required to produce units decline by employees. Mitchell Fein (1991) provided an example of an Improshare gain where 100 employees produced 50,000 units over a period of 50 weeks (200,000 hours needed to produce 50,000 units). These numbers are used to calculate the "base", which is $200,000 / 50,000$ or 4.0 hours per product. The base represents the expected amount of hours worked to produce one unit. During the period after Improshare is implemented, it is assumed that 102 employees produce 
1,300 units in 4,080 hours. According to the base calculated earlier, the value of this new production is 1,300 units $\times 4.0$ (base) $=5,200$ hours. The 5,200 hours represent the amount of time that, according to the base, the firm anticipates are required to produce the 1,300 units of production. Given an observed production time of 4,080 hours, a gain exists, which is split between the employees and management (5,200 - 4,080 $=1,120$ hours). This gain of 1,120 hours is split 50/50 between employees and management. The calculation then used to determine what each individual employee bonus will be is 560 (employee share of the savings) / 4,080 (actual hours worked), which is 13.7 per cent. Workers earn a corresponding bonus that equals $13.7 \%$ of their time worked (40 hours $\times 13.7 \%=5.48$ hours); the hours are then multiplied by the employee's hourly wage to determine the precise value of the payout.

\section{The Involvement System}

Most gainsharing plans, particularly the Scanlon and Rucker variety, recommend the installation of two tiers of suggestion committees, each empowered to approve suggestions submitted by workers.

The first tier committee is usually at the department level; suggestion committee members are normally elected by department members. It is the responsibility of these committees to encourage employees to make suggestions, and once received, review them, investigate if needed, and make final decisions on whether to implement the suggestion after careful cost/benefit analysis. If the cost of implementing the suggestion exceeds that of their budget authority, the suggestion is submitted to the second tier committee, which normally consists of a member from each of the first tier committees and a representative from top management. Suggestions having a favorable impact on the gainsharing formula result in bonus payments to the workers covered under the plan.

Now that we have examined the basic operational elements of gainsharing programs, the next section focuses on why and how gainsharing affects employee behaviors and conditions that are conducive to its successful implementation.

\section{THEORY BASED LITERATURE}

The theory based literature on gainsharing is diverse, encompassing both conceptual and empirical articles. Among the latter group, a wide ranging spectrum of methodologies is used including surveys, single case studies, multiple case studies, and experimental designs.

The ensuing literature review is organized around major theoretical perspectives which are also rather varied; these are grouped into three broad categories depending on their disciplinary roots, namely psychology, organization theory, and economics. Exhibit 1 highlights this material in terms of central focus, key hypotheses, and supporting evidence. 
GAINSHARING: SUMMARY OF THEORETICAL VIEWS AND EMPIRICAL FINDINGS

\section{THEORETICAL PERSPECTIVES PRIMARY FOCUS}

Socio-Psychological

1. Participative management Interpersonal relations

\section{Expectancy theory}

Cognitive reactions

3. Need theory

4. Operant conditioning

\section{Social dilemma}

6. Equity/justice theory

\section{Organizational}

7. Structural

\section{Contingency theory}

9. Social field theory

\section{Behavioral Economics}

10. Agency theory

11. Prospect theory

Internal drives

Free riding/personal responsibility

Perceived fairness

Social antecedents

Control

Framing of situation

\section{CENTRAL HYPOTHESIS}

Participation under gainsharing leads to greater employee commitment,

creativity, and performance.

Employees' predisposition toward gainsharing and observed behavioral response are a function of personal expectancies

Effectiveness of gainsharing depends on extent to which it fulfills employees' needs.

Reinforcement schedule

Behavioral impact of gainsharing depends on provision of social and financial reinforcement plus timely feedback.

External/contextual factors

Congruency/consistency

Group allocation of rewards induces greater individual efforts and reduces freeriding.

Effectiveness of gainsharing depends

Ex-ante situational variables determine relative success or failure of gainsharing

Effectiveness of gainsharing is a function of its fit with organizational idiosyncrasies and other human resource practices.

Gainsharing is most likely to be successfully implemented under strong pre-existing norms of high cooperation/high participation.

Mutual monitoring induced by gainsharing reduces agency costs.

Employees' behavioral response to

\section{RESEARCH AMOUNT} on perceived procedural/distributive justice gainsharing depends on perceived gain/loss context of decision making situation
Extensive

Very limited

Minimal

Unavailable

Minimal

Minimal

\section{EMPIRICAL SUPPORT}

Generally supportive

Generally supportive

Generally supportive

\section{Unavailable}

Generally supportive

Supportive

Very limited

Mixed

Very limited

Generally supportive

Very limited

Generally supportive

Very limited

Generally supportive

Unavailable

Unavailable 


\section{Socio-Psychological Perspectives}

Theoretical views falling in this category examine employee reactions to gainsharing in light of how they perceive the gainsharing program and how it affects them personally. These perspectives include the human relations/participative management school, expectancy theory, operant conditioning, need theory, equity theory, social dilemma, and procedural justice. Each of these is discussed in turn.

\section{Participative Management}

The oldest stream of theory based research on gainsharing focuses on the basic notion that inducing employees to cooperate by giving them voice and a chance to participate in important decisions regarding their jobs is likely to augment commitment to the organization, improve work motivation, and enhance overall productivity. Employees understand their jobs far better than management and tapping this knowledge through gainsharing offers an important means to increase organizational performance.

This view can be traced back to the classical writings of Mayo (1945) and his followers who argued that ". . the administrator is dealing with well-knit human groups and not with a horde of individuals. . . every social group must face two perpetual and recurrent problems of administration. It must secure for its individual and group membership: (1) the satisfaction of material and economic needs, and (2) the maintenance of spontaneous cooperation throughout the organization (p. 9) ... the eager human desire for cooperative activity still persists in the ordinary person and can be used by intelligent and straightforward management . . . " (p. 112) Gainsharing provides a medium to accomplish this by aligning the cooperation imperative of workers (through suggestion committee structures) with the objectives of the organization (through the criteria used to trigger payoffs) while at the same time satisfying the material and economic needs of workers (through the bonus system).

The notion that "genuine participation by the workers in regard to substantial matters is a good thing" (Cummings \& Molloy, 1977: 236) is a common thread in this literature, much of it concerned with the Scanlon plan described earlier. A total of ten empirical studies are reviewed next which follow from this theoretical tradition (see Exhibit 2). 
Exhibit 2

PARTICIPATIVE DECISION MAKING (PDM) BASED STUDIES

\begin{tabular}{|c|c|c|}
\hline AUTHOR(S) & $\begin{array}{c}\text { INDEPENDENT } \\
\text { VARIABLES }\end{array}$ & $\begin{array}{l}\text { DEPENDENT } \\
\text { VARIABLES }\end{array}$ \\
\hline Wallace (1971) & Scanlon plan implementation & $\begin{array}{l}\text { Management attitudes } \\
\text { toward employees and } \\
\text { PDM }\end{array}$ \\
\hline Burtnett (1973) & $\begin{array}{l}\text { Commitment to Scanlon } \\
\text { plan }\end{array}$ & Employee influence \\
\hline White \& Ruh (1973) & PDM and values & $\begin{array}{l}\text { Job involvement, } \\
\text { motivation, identification } \\
\text { with org. }\end{array}$ \\
\hline $\begin{array}{l}\text { Ruh, White, \& Wood } \\
\text { (1975) }\end{array}$ & Job involvement & Motivation, identity \\
\hline $\begin{array}{l}\text { Ruh, Johnson, \& Scontrino } \\
\text { (1973) }\end{array}$ & $\begin{array}{l}\text { Participation through } \\
\text { Scanlon Plan }\end{array}$ & $\begin{array}{l}\text { Job involvement, } \\
\text { motivation, } \\
\text { identification }\end{array}$ \\
\hline $\begin{array}{l}\text { Ruh, Wallace, \& Frost } \\
\text { (1973) }\end{array}$ & Gainsharing retention & $\begin{array}{l}\text { Management attitudes } \\
\text { toward employees and } \\
\text { PDM }\end{array}$ \\
\hline $\begin{array}{l}\text { Schuster (1984a; 1984b; } \\
\text { 1985) }\end{array}$ & $\begin{array}{l}\text { Scanlon Plan } \\
\text { implementation }\end{array}$ & $\begin{array}{l}\text { Production, } \\
\text { turnover, } \\
\text { absenteeism, } \\
\text { bonus, } \\
\text { suggestions }\end{array}$ \\
\hline $\begin{array}{l}\text { Hatcher, Ross, \& Collins } \\
\text { (1989) }\end{array}$ & $\begin{array}{l}\text { Pro-social behaviors, } \\
\text { job complexity }\end{array}$ & Suggestion making activity \\
\hline
\end{tabular}

The first four studies sought to explore the types of employee attitudes that, based on previous research and theory, should be present in organizations with participative decision making environments. Wallace (1971) surveyed 205 managers in 10 companies with Scanlon plans and in 8 firms that had discontinued the Scanlon plan. He hypothesized that managers in firms that had retained the Scanlon plan would have better morale than managers in firms without the plan. The results confirmed his hypotheses by discovering that managers in firms with existing Scanlon plans showed more favorable attitudes toward the firm, workers, and participative decision making in general. Although the results were consistent with his hypotheses it is not clear whether management attitudes were causally related to Scanlon plan retention or that the retention of the Scanlon plan resulted in a change in attitudes. Burtnett (1973) drew extensively from the participative decision making research to test a series of hypotheses whereby "the basic proposition underlying all hypotheses is simply that the perceived level of a certain organizational climate variable at one point in time is a contributing 
cause of the perceived level of a certain influence variable at a subsequent point in time during the implementation of a Scanlon plan" (p. 60). The results of his survey indicated that the employees' perceived level of commitment to the Scanlon plan (at time one) was the principal cause of perceived level of influence after the plan was in effect (at time two). The perception of the link between suggestions and the bonus payment at time one was also found to be a cause of perceived influence at time two.

White and Ruh (1973) developed a set of hypotheses stating that individual values should moderate the relationship between extent of participation and job attitudes. Their study focused on the role of ten individual values measured in a sample of employees working for six manufacturing firms that had implemented the Scanlon plan. The results indicated that individual values were directly related to employee participation, but their hypotheses stating that individual values acted as moderator between participation and job attitudes were not supported.

Ruh, White, and Wood (1975), in a study of 2,755 employees working in firms with Scanlon plans, investigated the relationship between job involvement, personal background, life values, and participative decision making. After reviewing the literature on participation in the workplace, they argued for a need to investigate the role of individual differences and hypothesized that job involvement should moderate the relationship between participation and job attitudes. Their results found correlational relationships between job involvement and the other variables included, but they did not substantiate the idea that job involvement acted as a moderator variable. Ruh et al. concluded that "job involvement may not be the appropriate moderator" or that "job involvement is not a stable value orientation brought to the job" (p. 311); therefore, in their opinion the findings should spur additional research to examine other potential individual level moderator variables.

Two studies specifically addressed Lowin's (1968) model of participative decision making which, according to Ruh, Johnson, and Scontrino (1973) "is basically a model of organizational change, the primary focus of which is on the conditions (i.e., the organizational, situational, and individual difference variables), which may facilitate or hinder change toward more participative decision making oriented systems of organization" (p. 2). Lowin's model places emphasis on the role of employee and management attitudes toward participative decision making and how those attitudes may affect the success of organizational change efforts. Ruh, et al. (1973) surveyed 2,488 employees in six different organizations to explore the relationship between attitudes toward participation through the Scanlon plan and three other job attitudes (job involvement, motivation, and identification with organization). They found support 
for correlational relationships between the variables specified above, but the causal order remained an open question.

An additional partial test of Lowin's model was conducted by Ruh, Wallace, and Frost (1973). They hypothesized that management attitudes should be related to gainsharing success and surveyed managers in 18 firms that had experience with Scanlon plans. Their results indicated that managers in firms that had retained the Scanlon plan had more favorable attitudes toward employees and participative decision making than managers in firms that had discontinued the plan. Both of these studies are cross-sectional, post-hoc, correlational designs that do not provide a strong test of causation.

Three studies, although not rooted directly on the participative decision making paradigm, utilized a model that is based on the parallel concept of union-management cooperation. Schuster (1984,,1984b, 1985) relied on the Kochan-Dyer (1976) stage model that details the conditions under which unions and management might consider a joint venture. Hypotheses developed from the model were then tested in firms with Scanlon plans. His empirical tests, utilizing an interrupted time series design, generally found favorable organizational outcomes after Scanlon plan implementation (increases in productivity, stable employment levels, bonus payments, and increased suggestion activity) attributable to improved labor-management cooperation.

The tenth and last study in this category relied upon the pro-social organizational behavior literature, which in this case was applied to suggestion making activity, considered by the authors to be a form of participation. Hatcher, Ross, and Collins (1989) reviewed the literature on pro-social behaviors and concluded that although suggestion making activity was considered a form of pro-social behavior it had not been investigated to date by researchers in the field. Given the importance of this activity in gainsharing environments, their study was designed to "identify some of the correlates of participation in gainsharing plan involvement systems" (p. 233). Hatcher et al. (1989) surveyed employees in five manufacturing firms with gainsharing plans. They found that suggestion making activity was correlated with other assisting behaviors, indicating that employees with a propensity toward one type of pro-social behavior tended to engage in similar activities. This relationship was moderated by job complexity, with high levels of assisting behavior being related to higher suggestion making activities for employees in jobs considered to be more complex.

In summary, a variety of studies have examined the role of participative decision making or a similar concept (e.g., union-management cooperation, pro-social behaviors) within a gainsharing environment. While results are somewhat mixed, for the most part they suggest that 
employee participation may be an important variable affecting the success of gainsharing programs. Three caveats are worth mentioning, however. First, the procedures used almost always leave open the question of causality and methodological artifacts (such as method variance, internal attributions, and social desirability biases), may account for some (perhaps most) of the positive findings. Second, because these studies are concerned with participative decision making, they do not attempt to tease out the singular and interactive roles of the bonus and employee involvement systems that are present in gainsharing environments. The role of the bonus system should not be underestimated (Geare, 1976; Hamner, 1988). Third, given the strong focus on the individual as the unit of analysis, this research has generally failed to take into amount the work group effect that should be present in a gainsharing environment (Welbourne, et al., in press)

\section{Expectancy Theory.}

Two studies conducted by Goodman and Moore (1976) and Moore and Goodman (1972) relied on expectancy theory to develop a learning model that posits individual, organizational, and interpersonal variables as predictors of employee reactions to Scanlon plans. Their model argues that employee perceptions of gainsharing is the result of two expectancies: (1) system expectancy (the perception that suggestion making is linked to receiving a bonus) and (2) self expectancy (the perception that an individual can submit a suggestion if effort is exerted). Goodman and Moore (1976) commented that "most research in this area has focused on predicting behavior from expectancies; this paper treats expectancies as the dependent variables" (p. 574). Their results indicated that individual level antecedent variables (e.g., education and understanding of reward system) affected managers' beliefs about the Scanlon plan while blue collar employees' beliefs were influenced more by organizational and interpersonal variables (e.g., nature of task, type of group) .

Because of its narrow focus on individual cognitive processes this line of work has not produced an extensive stream of research, such as that generated by the participative management models. Yet it reminds us that individual and demographic differences should not be ignored when testing hypothesis concerning gainsharing outcomes. As a case in point, Hatcher, Ross, and Collins (1991) interviewed 149 supervisors and non-management employees in five gainsharing companies; they found marked differences in individuals' willingness to be involved in the generation and assessment of suggestions. The key variable explaining this predisposition was the employee's instrumentality belief, that is "the perception that the gainsharing system either benefits or works to the detriment of a given individual's interest" (p. 40). Interestingly enough, the expectancy most often mentioned by employees as a 
determinant of suggestion activity in this study is congruent with the participative management perspective reviewed earlier. The perceived ability to collaboratively improve performance and become involved in work decisions is the main predictor of suggestion activity with "the desire for influence more influential than the desire for bonuses" (Hatcher et al., 1991: 41). A caveat similar to that mentioned earlier under the participative management discussion also applies here. The nature of the methodology used would tend to increase social desirability biases because individuals may attribute their willingness to be involved to "good" things (e.g., ability to help others and make personal contributions) without publicly acknowledging private motives with negative connotations (such as selfish greed as reflected in the desire to attain a bonus).

\section{Need Theory}

Along similar lines to the research reviewed above, some investigators have noted that individual needs mediate the relationship between gainsharing and its outcomes. To the extent that the gainsharing plan satisfies an individual's needs, the more likely the employee will respond in the desired direction. One study, conducted by Dreher (1980), relied on individual need theory as specified by Murray (1938) and later expanded by McClelland et al. (1953) and Atkinson (1958) to examine the relationship between individual need strength with job satisfaction and job involvement. The study was conducted in a firm with a modified Scanlon plan and measured four needs: achievement, affiliation, autonomy, and dominance. Dreher found that all of the needs except the need for affiliation correlated significantly with both job satisfaction and job involvement. After reviewing the results, the author suggested that "individual differences may play an important role in understanding the Scanlon plan process" (p. 93). Once again, this conclusion serves as an admonition to those who propose a generalized approach to gainsharing based on what may prove to be simplistic assumptions concerning employees' predisposition (e.g., universal desire to participate in a team context). Unfortunately very little research has been conducted along these lines even though Dreher's study was published 15 years ago.

\section{Operant Conditioning}

A recent theoretical article by Mawhinney and Gowen (1991) focuses on the pecuniary properties of gainsharing from a reinforcement perspective. Using operant conditioning principles drawn from the experimental psychology literature, these authors argue that most effective gainsharing programs meet three criteria. First, the bonus should follow accomplishment of performance targets with minimal delays. Second, the work group should provide social reinforcement for high performance. Lastly, the negative effects of delayed rewards should be mitigated through system components that provide feedback. In other words, 
feedback can compensate for delayed reinforcements under gainsharing. While empirical tests of these notions remain to be conducted, this paper brings into sharp focus the importance of examining reinforcement schedules in gainsharing programs--something that is largely ignored in the models reviewed so far.

\section{Social Dilemma}

One of the concerns with aggregate incentive systems such as gainsharing is the so called "free-riding" effect whereby individuals accrue the benefits of the group effort and this serves as a disincentive to individual efforts (Gomez-Mejia \& Balkin, 1992a). In the terminology of Cooper, Dyck, \& Frohlich (1992), gainsharing creates a social dilemma because employees can benefit from an improvement in group performance regardless of their personal contribution to that performance. In a manner akin to the participative management models, Cooper et al., argue that this social dilemma may be solved through group decision making to decide how rewards are to be allocated within the group. Specifically, "when people participate in developing a rule of distribution of income, they will choose to take into account both the needs of the least productive and the entitlements of the higher achievers" (Cooper et al., 1992: 473). According to the authors, only when this condition is met will the organization realize significant productivity gains. Any distribution rules imposed from outside the group will not produce the same effect; in fact, they are likely to augment a social dilemma whereby individual and group incentives diverge.

Cooper et al. found support for the above proposition in a lab experiment with students as subjects. The generalizability of the findings to large, complex organizations remains to be shown. However, their essential message (that intrateam allocation of rewards is important to reduce free-riding) has enormous implications for the design of gainsharing programs. It complements participative management models by emphasizing the importance of differential distribution of aggregate rewards as part of the group decision making process.

\section{Equity and Justice Theories}

The central argument in this literature is that employees' response to gainsharing depends on their perceptions of the program's fairness. About 20 years ago, Geare (1976) criticized much of the earlier literature on gainsharing because it deemphasized and underestimated the importance of pecuniary rewards. He argued that much of the previous research advocated participation as key to gainsharing success, ignoring the incentive properties of the bonus. Geare pointed out, after reviewing mixed research evidence of the role of participation in decision making, that it is the lure of money rather than the appeal of participation that leads to changes in employee behaviors in response to gainsharing. As a 
corollary, Geare noted that perception of equity is a necessary precondition for the gainsharing bonus to induce desired employee behaviors.

Hammer (1988) presented a model of gainsharing based on Geare's ideas. According to Hamner's model the bonus provides the impetus for participation, which is the key to change in employee effort. The model indicates that the bonus acts to influence participation when it is promised and again when it is received. In other words, the promise of equity in the contractual relationship between employer and employee creates the conditions for participation to occur. In turn, participation can only be sustained if appropriate reward contingencies exist that are perceived as equitable.

Welbourne et al. (in press) expand on this theme by drawing from the justice literature in organizational behavior which argues that perceived fairness of outcomes and procedures exerts a strong influence on how employees react to gainsharing. From this perspective the effectiveness of gainsharing in terms of eliciting desired employee behavior depends on the joint presence of distributive and procedural justice. The process through which decisions are made forms the basis of perceived procedural justice. This is in contrast to the concept of distributive justice which is concerned with the perceived fairness of the consequences of those decisions (i.e., gainsharing bonus).

An empirical study by Welbourne et al. (in press) based on two samples of workers drawn from two firms using two different types of gainsharing programs (one similar to a Scanlon Plan and one analogous to Improshare) found support for the notion that employees' participation (in terms of suggestion activity and job involvement) is a positive function of both distributive and procedural justice. These authors concluded that workers are more likely to contribute if they believe that high rewards are commensurate with those efforts (distributive justice). Likewise, lack of perceived procedural fairness creates a cognitive discrepancy for the employees involved, lowering their relative contribution to the program. While both forms of justice are important, the authors found in a manner consistent with the organizational justice literature (e. g., Folger \& Konovsky, 1989) that in a gainsharing plan the perceived fairness of procedures may be more important to workers than the perceived fairness of outcomes received.

In summary, the equity and justice based models serve to link the gainsharing literature to much of the "mainstream" organizational behavior and compensation research that accords perceived fairness a pivotal role. These models also raise a red flag concerning the dangers involved with the implementation of gainsharing programs which do not explicitly take into account employees' perceptions of the rewards. They also provide a complementary theoretical 
structure to strengthen the conceptual power of the participative gainsharing models. This is because employee involvement in the design of the gainsharing program and the allocation of rewards is highly correlated with procedural justice, which in turn affects extent and value of future participation (Welbourne et al., in press).

\section{Organizational Perspective}

The organizational perspective focuses on gainsharing at the firm level of analysis or at the interface between the firm and its environment. The effectiveness of gainsharing is analyzed primarily in terms of contextual factors. This literature may be divided into three categories, which are discussed in turn: structural, contingency, and social fields.

\section{Structural Models}

Structural models argue that organizational factors or conditions that exist prior to implementation of gainsharing ultimately determine its relative success. Therefore gainsharing has little chance of succeeding unless these ex-ante conditions are explicitly addressed in the design and implementation phases. A key concern in this literature is the identification of those a priori factors that facilitate or hinder the effective execution of gainsharing.

The best known structural model of gainsharing was introduced by Frost, Wakeley, and Ruh (1974), who accumulated data and expertise as a result of their consulting experience with a number of firms installing gainsharing plans. They relied on their experience as consultants and the organizational development literature to create a complex model that includes identity (employee identification with the organization), participation (participative decision making), equity (fair renumeration), and managerial competence (the ability of managers to do their jobs) as necessary preconditions of gainsharing success or effectiveness. Although Frost et al.'s model has generated a considerable amount of interest, Schuster (1983a) comments that it "has not proven useful for generating or testing hypotheses" (p. 59). In fact, the only empirical test conducted to date that has been directly linked to their model was generated by Greenwood (1977) who developed an instrument to measure the four constructs proposed in the model. Using a survey methodology, their results indicated that scores on all four constructs were higher in firms that introduced and retained Scanlon plans. Unfortunately, the cross-sectional nature of the design does not allow for any inference of causation; it is not known whether the levels of identity, participation, equity, and managerial competence were determinants of gainsharing plan retention or whether gainsharing plan installation and retention caused the changes to occur.

Graham-Moore and Ross (1983) proposed an analogous model to predict gainsharing success. They list organizational (climate, size, technology, policy, reward systems, identity), 
socio-cultural-institutional (union and industrial relations climate, workforce characteristics, external environmental, geographic factors), individual (managerial philosophy, trust, locus of control, skill level, motivation, satisfaction), and financial (accuracy, budgets, control, knowledge of competition, government constraints, etc.) variables as factors that determine gainsharing success or failure.

Bullock and Lawler (1984) adopted a similar approach and developed a comprehensive model of gainsharing based on their review of 33 case studies. They categorized the determinants of gainsharing success as being either (1) structural (suggestion committees, financial formula, payout percentage, etc.), (2) implementation (employee involvement, objectives, use of interventionist, etc.), or (3) situational (size, union status, management style, technology, environment, etc.) factors. A subsequent reexamination of these 33 plans by Bullock and Tubbs (1990) using a case meta-analytic technique indicated that four structural features predicted gainsharing success: employee involvement in plan design, use of outside practitioners, formal involvement structures, and employee favorability toward the plan. The authors conclude that "with the exception of participative management style, situational conditions did not correlate with gainsharing's success. Success was robust across organizational size, union status, technology and environment." (p. 384).

This literature contributes to our understanding of gainsharing by reminding us that these plans should not be introduced (or indeed studied) as stand alone entities without simultaneously examining other organizational factors that may singularly or interactively affect their success. However, this literature suffers on three counts: First, the empirical tests, so far, leave open the question of causality. Second, the identified factors (perhaps because of their global, often amorphous nature) are difficult to measure and the theoretical constructs themselves are subject to a wide range of interpretations. Third, it tends to neglect the possibility that the gainsharing program may be introduced as a change agent to alter the conditions which have been identified as prejudicial to these plans (such as low employee identification with the firm and lack of control or empowerment).

\section{Contingency Theory}

Contingency theory as applied to gainsharing dovetails the structural models discussed above. The central tenet of contingency theory is that lack of fit between two or more elements of a system reduces its overall effectiveness. In other words, the performance of the system in total is a direct function of the match between its various components. In the special case of gainsharing, effectiveness is predicated on its fit with other organizational factors, rather than as an independent phenomena that can be examined out of context. 
Empirical tests of these contingency notions specifically applied to gainsharing are hard to find. Yet, indirect evidence is supportive of a contingency approach to the study of gainsharing. A study by MacDuffie (1994) of 70 automobile assembly plants led the author to conclude that "bundles of interrelated/internally consistent HR practices are the appropriate unit of analysis for studying the link [of gainsharing] to performance--rather than individual practices--because they create the multiple, mutually reinforcing conditions that support employee motivation/skill acquisition" (p. 3).

A similar study was conducted by Ichniowski, Shaw, and Prennushi (1994) using a sample of 45 business units in 21 steel manufacturing companies. In a manner analogous to MacDuffie (1994), these authors concluded that "systems of complementary HRM practices raise firm's productivity. These effects of HRM systems are much larger than the productivity effects due to individual practices. Firms cannot make marginal decisions with regard to HRM practices but instead will realize the largest increases in productivity from making discrete jumps in the use of clusters of practices" (p. 6). Gomez-Mejia and Balkin (1992a) reviewed several earlier compensation studies that agree with these contingency notions.

In summary, contingency theory provides a well established conceptual framework with a wealth of prior empirical studies in diverse areas that can be readily applied to study the fit between various types of gainsharing programs and contextual factors, and how their congruency affects observed results. Thus it can provide more rigor to the structural factors approach reviewed earlier. Several empirical techniques are available to examine degree of congruency or fit (Gomez-Mejia \& Balkin, 1992a); unfortunately these require large sample sizes, limiting their application to gainsharing because the firm (rather than the individual) is the unit of analysis.

\section{Social Fields}

This perspective is based on Lewin's (1947) social field theory. The objective is to explain whether or not gainsharing is more likely to be implemented and be effective under favorable conditions, or whether it can be introduced successfully under adverse conditions that management desires to change.

Collins, Hatcher and Ross (1993) developed two competing gainsharing models along this line. The first model, labeled compatibility, argues that gainsharing is most likely to be introduced and be successful in facilities with the fewest restraining forces (i.e., most favorable conditions). "In this sense, gainsharing boosts the facility from a good to a relatively better level of operations" (Collins et al., 1993: 79). At the opposite extreme, a transformation model predicts that gainsharing is most likely to be adopted and have the greatest positive effects on 
the organization in facilities with the greatest restraining forces (i.e., unfavorable conditions such as a negative work climate that management wishes to change). Under the transformation model, the objective of gainsharing is to raise the facility ". . from a relatively poor level of operations to a relatively better level of operations. It is consistent with other models of organizational change which state that innovations are more likely to be adopted and/or succeed when there is a strong perception of a need for change" (Collins et al., 1993: 80).

The authors tested these competing models by collecting data on work climate (e.g., participation levels) via a survey of 485 upper level managers in 59 facilities. Of these 59 facilities, 17 subsequently implemented a gainsharing program. The results showed no support for the transformation hypothesis and weak support for a compatibility explanation. The authors concluded that "while gainsharing is often promoted as a means for achieving greater levels of involvement, the present results suggest that it is more likely to actually be implemented in settings where there are already higher levels of cooperation and in nonunion facilities where there are already higher levels of participation" (p. 101).

The longitudinal design of Collins et al.'s study is a rarity in the gainsharing literature and clearly is an improvement over much of the cross-sectional work that has been reviewed up to this point. Lewin's social field notion also provides additional insights concerning the precursors of gainsharing and its effectiveness. However, the conclusion of the study needs to be tempered by the fact that the sample size was small and no data was available on the effectiveness of gainsharing, only the implementation rate. For instance, it is possible that gainsharing as an intervention may have the greatest positive effects on reversing dysfunctional conditions (e.g., a negative work climate and low employee participation). Yet these adverse conditions may act as restraining forces reducing the probability that gainsharing is introduced in the first place.

\section{Economic Perspective}

The body of literature taking an economic perspective to gainsharing is minimal, yet organizational economics offers some powerful analytical models that may provide some important insights in this domain. Two of these conceptual frameworks are discussed next: agency and behavioral theory of the firm.

\section{Agency Theory}

An agency relationship involves any situation where decision making responsibility is delegated to a second party for a fee (Zajac, 1990). Examples of agency relationships include: professionals and clients, insured and insurer, shareholders and management, and society with a polluting firm (Shavell, 1979). Jensen and Meckling (1976) extend the definition by noting that 
any cooperative situation, even those that are not obviously a principal-agent relationship (e.g., volunteer organizations, co-authoring a paper), can be considered as such.

Within an organization an agency relationship exists not only between the owners and top management but also between the managers and employees. Eisenhardt (1985), for example, applied the concept of agency in a study of pay practices for retail salespeople in a sample of 54 stores, thus extending the concept beyond owners and top executives. GomezMejia and Balkin (1992b) studied faculty pay allocations in an agency context with faculty portrayed as agents and the administration as principals. As discussed below, gainsharing programs can also be analyzed in terms of the agency relationships that are present.

\section{Agency costs}

The problem of agency results from the assumed utility maximizing behavior of both principals and agents. Moral hazard is one type of agency problem that may be attributed to the purported self-serving and opportunistic behavior of the agents (Kotowitz, 1989). The work environment is described as a situation where agents can make decisions to maximize their self interest, often at the expense of the owners or principals (Barney \& Ouchi, 1986). The term moral hazard originated in the insurance industry, where an insurance policy created incentive for the insured to cause an accident (such as an intentional fire) (Arrow, 1985).

Moral hazard and adverse selection, the second agency problem, result from information asymmetries that provide one party (agents) with information that is not available to the second party (principals) (Gomez-Mejia \& Balkin, 1992 $b$ ). Adverse selection refers to the principals' inability to make correct decisions because they do not have complete information on a work-related subject. For instance, the concept is often applied to the topic of hiring. Principals do not have complete information on the agent (who may withhold critical information on the agent's mistakes) and can only infer their qualifications from data provided by the agent (Zajac, 1990). This could result in decisions that are less than optimal from the principal's perspective. Agency theory thus focuses on how to reduce the agency problem, which translates into minimization of agency costs. Agency costs include: 1) monitoring costs incurred by the principal in an effort to keep abreast of the actions of the agent (e.g., hiring supervisors, implementing incentive systems, enacting budget controls, etc., 2) bonding costs incurred primarily by the agent (but often the principal must incur some administrative costs such as audits) to guarantee the principal that the agent is not performing outside the boundaries intended by the agent; and 3) residual loss, which is defined as the inevitable loss incurred by the principal because it is impossible for principals to use monitoring or bonding arrangements 
to guarantee $100 \%$ full compliance by the agent (Barney \& Ouchi, 1986; Dyl, 1988). Thus, from the perspective of the principal, the equation to be minimized is as follows:

Agency Costs $=f(M+B+R)$,

where $\mathrm{M}=$ monitoring; $\mathrm{B}=$ bonding; $\mathrm{R}=$ residual loss When the principal makes no attempt to minimize agency costs through the use of monitoring and bonding agreements, the total cost is equivalent to residual loss.

The goal of the principal is to minimize agency costs. Transferring resources to monitoring and bonding is rational to the extent that this action would reduce residual loss at a greater rate than that incurred by implementing these types of controls. If the principal invests funds in developing, executing, and monitoring contracts with agents to minimize agency costs, and these efforts do not reduce the residual costs then total agency costs could actually increase (Stiglitz, 1989). For instance, excessive executive monitoring may increase residual loss rather than reduce total agency costs by making the executive too risk averse (Tosi \& Gomez-Mejia, 1994).

Various control mechanisms may be utilized by firms to control employee behaviors and thereby reduce agency costs. Other things equal, the "optimal contract" is characterized as one where complete monitoring of the agent by the principal can be done, thus minimizing residual loss as much as possible (Eisenhardt, 1985; Holstrom, 1979). This suggests a negative linear relationship between residual loss or total agency costs and monitoring and bonding behaviors where agency costs and residual loss would be minimized at the point where complete monitoring could be conducted (see Exhibit 3). 


\section{Relationship between agency costs, residual loss, \\ and lovel of monitoring activity.}

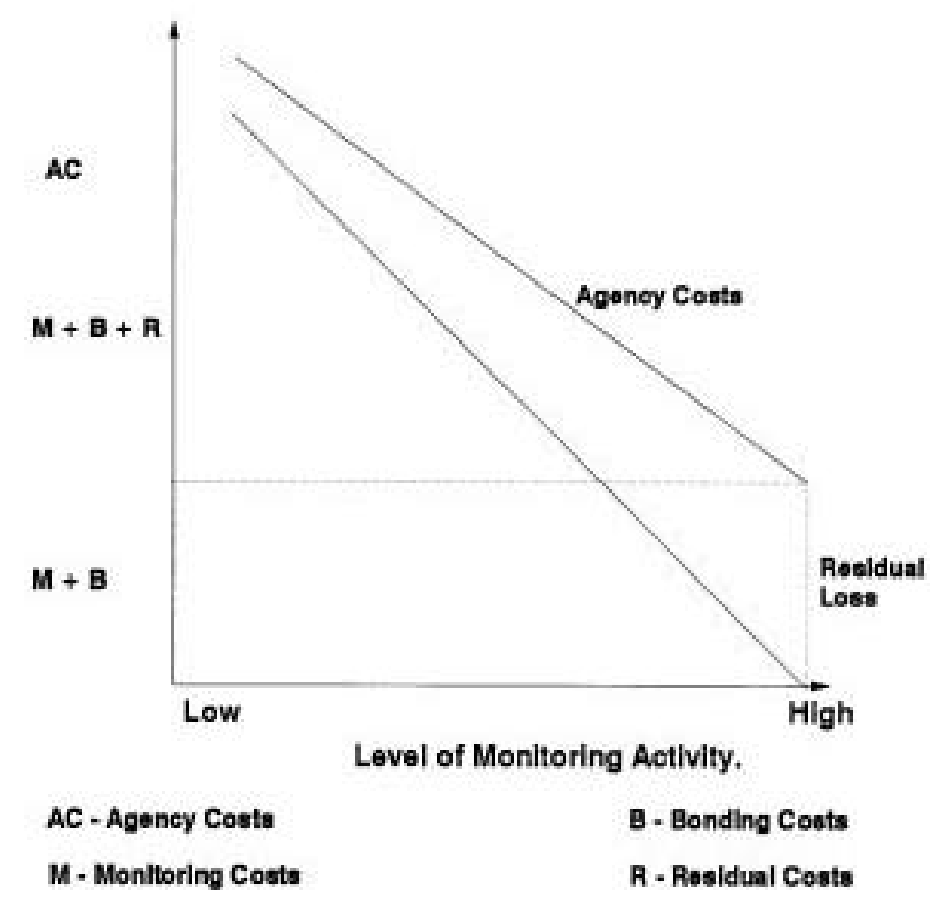

Given the fact that many employment contracts must be specified under conditions where the agents' work behaviors cannot be easily programmed or monitored by the principal (such as executive, management, and sales positions), the principal may rely on incentive contracts as an alternative to supervision. In this manner, the interests of both parties coincide so that incentives may act as a form of agent self-monitoring (Gomez-Mejia, 1994) . For production workers the most widely used option for minimizing agency costs has been agent monitoring rather than incentive alignment. This is normally accomplished through the employment of supervisors, use of extensive policies and procedures (such as a probationary period and progressive discipline), development of detailed job descriptions, and the administration of performance appraisal (Gomez-Mejia, Balkin \& Cardy, 1995).

Welbourne and Gomez-Mejia (1995) argue that this form of control may lead to a reduction in residual loss that is greater than the increase in monitoring and bonding costs. This occurs whenever employees conform to behaviors dictated by managers who have incomplete information about the task. This conformity causes employees to be complacent, and they have no incentive to search for more effective ways of performing the job. Welbourne and 
Gomez-Mejia (1995) refer to this phenomenon as "the behavioral cost of monitoring." As jobs become more complex and interdependent, and as the supervisor lacks the technical "know-how" to effectively monitor worker's performance or write effective job procedures, excessive controls over employee behavior can thus result in either decreases in residual loss that are lower than expected or even increases in residual loss if the "hidden" behavioral cost of monitoring is sufficiently high.

In other words, employees exposed to excessive control or monitoring might not take the initiative to find creative solutions to problems or make suggestions for more efficient means of conducting their jobs. Due to these behavioral responses, it is possible that additional monitoring may simply transfer agency costs from residual loss to monitoring costs or potentially augment total agency cost. Graphically, this relationship can be depicted as a U-shaped curve: at some point greater levels of monitoring activity will actually augment total agency costs because in addition to increased monitoring costs, the behavioral cost of monitoring begins to supplement residual loss (see Exhibit 4).

\section{EXIIIEII 4}

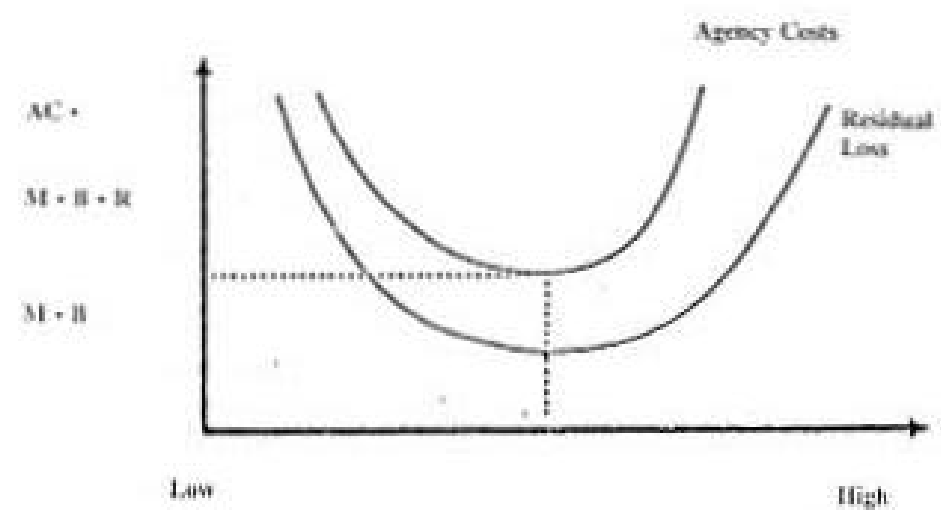

According to Welbourne and Gomez-Mejia (1995), gainsharing may be conceptualized as a different form of monitoring that helps prevent the dysfunctional effects noted above. Gainsharing attempts to minimize agency costs through reduction of both monitoring and residual loss rather than merely transferring costs from residual loss to monitoring costs. Through the use of a contract that has both behavioral and outcome-oriented components, the 
firm encourages employees to behave in a manner consistent with the needs of the principal. Gainsharing reduces monitoring expenses incurred by the principal because it encourages employees to monitor each others' performance. It also reduces residual costs, including the behavioral cost of monitoring, because workers are encouraged to find and implement innovative procedures within their work environment.

From this perspective, gainsharing can be viewed as an attempt to transfer a business unit from a traditional hierarchical organizational design to one that is more similar to what Fama and Jensen (1983) describe as existing within a formal partnership (Welbourne et al., in press). Partnerships (such as those found in legal or accounting firms) create an environment where all the members share the business risk and also share the wealth (gains or losses incurred by the partnership). Gainsharing plans create an agency relationship between top management and the members of the gainsharing unit, thus risk is spread among all members of the unit, and gains and losses are also shared among the members of the unit. Given the contract terms of this new agency agreement, the behavioral consequences of gainsharing should be consistent with the behaviors found within teams and between work teams that are part of professional partnerships.

Specifically, internal monitoring both within a work team and between work teams should increase as a result of gainsharing implementation. Fama and Jensen (1983) discuss internal or mutual monitoring as follows: "When agents interact to produce outputs they acquire low-cost information about colleagues, information not directly available to higher level agents. Mutual (internal) monitoring systems tap this information for use in the control process" (p. 310). In a partnership, due to the fact that the members are interdependent, this "mutual monitoring" should elicit worker behaviors that eventually lead to achievement of organizational goals and objectives.

Therefore, gainsharing plans should be associated with lower levels of formal monitoring (such as direct supervision; work procedures and policies) of participating employees. Gainsharing plans transfer part of the role of monitoring from the supervisors or managers to the employees through implementation of suggestion committees. The suggestion committees are staffed by a group of peers whose goal is to review employee suggestions and approve those that appear to meet the cost/benefit criteria established by the suggestion teams. Gainsharing plans thus formally encourage employees to derive new work methods and to share their innovative ideas with the suggestion committees (a committee of peers). The incentive alignment system (i.e., bonuses) serve to reinforce these behaviors and induce greater mutual monitoring. 
Following the above logic, gainsharing plans substitute a different (and less costly) form of control for direct supervision. It is expected that within and between employee teams, gainsharing plans encourage stronger levels of peer group pressure to enforce work norms consistent with the business unit goals. Agents have an opportunity to acquire low-cost information about their peers due to the fact that they work with these individuals on a regular basis. Gainsharing thus takes advantage of this type of group process. Rather than expending resources to create surveillance systems that attempt to track employee performance and behaviors, the firm encourages employees to monitor each other and to use this information to assure that each worker is attaining the goals of the work group. Internal monitoring can be formal, through the suggestion committees, or informal, through peers.

In short, when gainsharing plans are implemented, agency costs borne by the principal are reduced by transferring some of the monitoring activities from the principal to the agent. In addition, peers have greater opportunities to observe each others 'performance; therefore, it may be more difficult for agents to shirk when peer pressure rather than supervision or extensive policy and procedure enforcement represents the sanctioned form of control. Because mutual monitoring is a more efficient form of control, gainsharing should enhance firm performance which benefits both owners (through greater profits) and employees (through the bonus system).

Welbourne et al. (in press) conducted some limited empirical tests of these agency based predictions by developing a composite scale of mutual monitoring administered to employees of two companies that had implemented gainsharing programs. Mutual monitoring was assessed before the gainsharing plan was introduced and three quarters after the plan had been in effect. The results indicated that gainsharing increases mutual monitoring as the theory predicts. Yet, there is one important qualification: This effect only occurs when the employees involved believe that both procedural and distributive justice are present. This study suggests that use of agency theory in combination with other behavioral perspectives (such as equity theory) can provide a robust framework to study gainsharing issues. The study itself, however, suffers from several limitations that would need to be addressed in future research. Three in particular are salient. First, monitoring was self-reported. Second, the time frame under consideration was relatively short (i.e., nine months). Third, only two companies were involved in the study so that the firm performance implications of mutual monitoring could not be ascertained. However, the findings of the study are encouraging and suggest that more agency-based research on gainsharing should be conducted in the future. 


\section{Behavioral Decision Theory}

An underlying assumption of agency theory is that agents are risk averse and make decisions to reduce their risk exposure (Fama \& Jensen, 1983). A parallel literature under the rubric of behavioral decision theory argues that agents are not uniformly risk averters but may be risk seeking under certain conditions. From this perspective, the key factor that determines risk seeking or aversion is the performance context facing the decision maker. Specifically, decision makers are expected to be risk averse in the domain of gains and risk seeking in the domain of losses (Kahneman \& Tversky, 1979). Many studies have confirmed this relationship both for individual managers as subjects (e.g., Crum, R., Laughhunn, D., \& Payne, J. W., 1980; \& Laughhunn, D. J, Payne, J. W. \& Crum, R., 1980; Fishburn \& Kochenberger, 1975; Puto, 1987) and for the organization as the unit of analysis (Fiegenbaum \& Thomas, 1986, 1988; Singh \& Montgomery, 1987). For instance, in what became known as the Bowman's paradox, Bowman $(1980,1982)$ found that firms facing lower returns took more risks than firms experiencing higher returns. It was labeled a paradox because most organizations were believed to be risk averse and risk averse organizations would only undertake riskier projects if these were expected to deliver a high return. Thus his findings and that of many others (see review by Sitkin \& Pablo, 1992) confirmed behavioral theory's prediction of greater risk seeking behavior of firms with poor returns (in the domain of losses) as compared to firms with high returns (in the domain of gains).

In a conceptual paper, Welbourne and Gomez-Mejia (1995) argue that a similar relationship should be found in gainsharing plans. As noted earlier, most gainsharing plans require participating employees to generate, evaluate, and implement suggestions.

Corresponding decisions vary in their level of risk (e.g., some suggestions are more costly than others; some suggestions are associated with more uncertain outcomes than others; implementation may require minimal or extensive changes in work design and so forth). If performance context is an important determinant of decision risk for individuals and organizations, it seems equally valid that differences in the performance criteria used to trigger gainsharing bonuses may produce very different risk taking behaviors among workers. In other words, under the identical gainsharing plan agents (workers) may be risk seeking or risk averse depending on the nature of the performance facing them at the time. This hypothesis remains to be tested empirically.

\section{Concluding Comments on Theory Based Research}

In summary, the theory based literature on gainsharing has engendered numerous hypotheses concerning the variables that influence the effectiveness of these plans and 
conditions that mediate their relative success. These explanatory frameworks are complementary rather than competing, although little is known in a comparative sense as to which ones account for more variance in predicting gainsharing outcomes. It seems fruitful at this point to begin integrating constructs and relationships from various paradigms to develop a more powerful and comprehensive gainsharing model that incorporates individual, organizational and environmental dimensions.

Clearly, there is a sore need for more gainsharing data that is grounded in theory. With the exception of the empirical literature falling under the participative management umbrella, much of which is methodologically weak, the remaining theoretical formulations show sparse supporting evidence. It is also worth noting that the socio-psychological perspectives reviewed here attempt to predict individual behaviors in a gainsharing environment, but to date the studies that consider the individual as the unit analysis rely almost exclusively on attitudinal data.

\section{DESCRIPTIVE LITERATURE}

The bulk of the extensive gainsharing literature is a theoretical and exploratory in nature. A review of these publications by Milkovich (1987) almost a decade ago led him to conclude that "the literature is dominated by descriptions of various plans and prescriptions of how to use them" (p. 4). A few years later, Graham-Moore and Ross (1990) note in their review book on the subject that "gainsharing has been part of the incentive and industrial relations field for fifty years, yet full understanding of why it works has eluded behavioral science." More recently, Welbourne et al., (in press) came to similar conclusions by noting that most of the descriptive literature is based on the notion that participation drives gainsharing results yet these ideas are loosely specified, often written from an advocacy perspective that employee involvement (through gainsharing) is conducive to greater organizational effectiveness. This is unfortunate in light of the rich theoretical background (as summarized in Exhibit 1 and earlier discussions) that could be brought to bear on these issues. In spite of it's a theoretical nature, the descriptive literature is reviewed next both because it represents the majority of the publications on gainsharing and because it may complement some of the more rigorous research discussed earlier. According to the categorization system that will be employed, the descriptive literature falls into one of three classes: field studies (Exhibit 5), exploratory surveys (Exhibits 6) and conceptual articles (Exhibit 7). 


\section{EXHIBIT 5}

\section{Listing of Descriptive Field Studies}

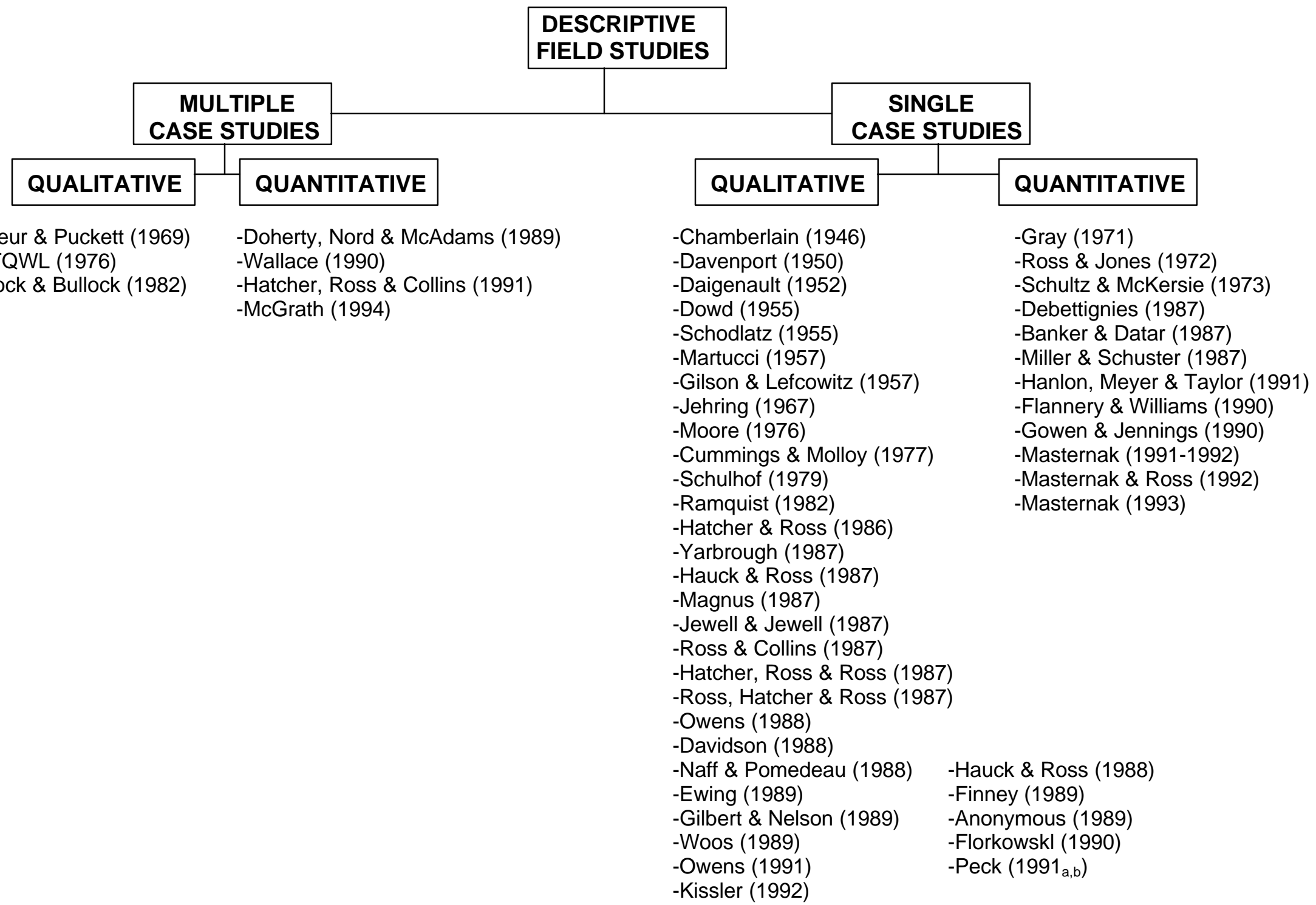




\section{EXHIBIT 6}

\section{Listing of Exploratory Surveys Literature}

-Goodman, Wakeley \& Ruh (1972)

-White (1979)

-US GAO Study (1981)

-Hauck (1986)

-Freud \& Epstein (1984)

-Hauck (1986)

-US GAO (1986)

-Hatcher \& Ross (1986)

- Voos (1987)

-O'Dell \& McAdams (1987)

-Lawler, Ledford \& Mohrman (1989)

-Long (1989)

-Ost (1990)

-Nickel (1990)

-Kaufman (1992)

-Markham, Scott \& Little (1992)

-Lawler \& Cohen (1992)

-Alexander Consulting Group (1992)

-Wyatt Data Services (1995) 
EXHIBIT 7

Listing of Conceptual Gainsharing Publications

\begin{tabular}{|l|}
\hline $\begin{array}{l}\text { CONCEPTUAL } \\
\text { LITERATURE }\end{array}$ \\
\hline
\end{tabular}

\section{GENERAL}

-Schultz (1961)

-Krulee (1966)

-Whyte (1966)

-Strauss \& Sayles (1967)

-Lesleur (1958)

-Lesleur (1969)

-McGregor (1980)

-Doyle (1970)

-Smith \& Gude (1971)

-Lane (1976/78)

-Daly (1976)

-Hackman \& Suttle (1977)

-Cummlngs \& Molloy (1977)

-Frost (1978)

-NCQWL 1978)

-Driscoll 1978)

-O'Dell (1981)

-Lawler (1981)

-Doyle (1982)

-Greham-Moore \& Ross (1983)

-Ross (1983)

-Doyle (1983)

-Hatcher \& Ross (1983)

-Ross \& Hauck (1983)

-Ross \& Ross (1984)

-Metzger (1986)

-Lawler (1986)

-Dar-El (1988)

-Florkowski \& Lifton (1987)

-Miller \& Schuster (1987)

-Hauck (1987)

-Schuster \& Miller (1987)

-Dulworth \& Usllaner (1987)

-Ross, Hatcher \& Ross (1987)

-Thor (1987)

-Owens (1988)

-Peterson \& Tracy (1988)

-Scott (1988)

-Gross \& Backer

-Ewing (1989)

-Nickel \& O'Neal (1990)

-Lawler (1990)

-DeBettignies (1991)

-Milkovich \& Milkovich (1992)

-Imberman (1992)

-Milkovich (1993)
-Hammerstone (1987)

-Markham \& Scott (1988)

-Thomas \& Olson (1988)

-Musselwhite (1988)

-Milkovich \& Milkovich (1992)

-Nichols (1989)

-Graham-Moore \& Ross (1990)

-Paulson (1991)

-Rock \& Berger (1991)

\section{LITERATURE REVIEWS}

-Moore (1982)

-Schuster (1983)

-Milkovich (1987)

-Bullock \& Tubbs (1990)

-Lawler (1988)

-Welbourne \&

-Gomez-Mejia (1988)

-Gowen (1990)

-Beck 19

-Bailey(1993)

-Masternak (1993-1994) 
The conceptual category (see Exhibit 7) consists of eight literature reviews, and 60 general articles that introduce the reader to the concept of gainsharing. The majority of these articles are geared for the practitioner and provide a brief overview of the concept of gainsharing, where and when it is applicable, and how to install such a plan. Most of them stress the beneficial aspects of gainsharing (such as positive employee relations, improved quality, enhanced cooperation, and better communications) and seem to be written by authors (often consultants) who are advocates of gainsharing. In addition, this literature provides technical information concerning gainsharing formulas and other specific details on how these plans have been administered and implemented. These publications will not be discussed here due to their general nature and limited space; however, they are listed as a source of reference in Exhibit 5.

Descriptive publications encompassing field studies (Exhibit 5) and exploratory surveys (Exhibit 6) are discussed in the next two sections.

\section{Descriptive field studies - multiple cases}

A total of seven gainsharing studies are included in this category. Three of these are qualitative or narrative in nature and four report some type of numeric indicators (see left hand side of Exhibit 5).

\section{Qualitative studies}

The earliest qualitative study using multiple cases was published by Lesieur and Puckett (1969) who examined Scanlon plans that were installed at Atwood Vacuum Machine Company, Parker Pen Company, and Pfaudler. They listed the conditions under which the plans were implemented and included general comments on some of the realized results, which included positive employee relations, improved quality, enhanced cooperation, and better communications.

The National Center for Quality in Working Life or NCFQWL (1976) published an extensive report that included detailed information on the Scanlon plans installed at both Dana Corporation and Parker Pen. The NCFQWL also included comments on the work climate prior to installing gainsharing, the types of problems that led to a search for an alternative rewards program, and the results of the plan. Both firms report positive outcomes including enhanced union-management relations, bonus payments, suggestions, increased production, and employee acceptance of new technology.

The last paper in this category, by Bullock and Bullock (1982), describes gainsharing plans at two anonymous firms, Company A (a small steel fabrication plant) and Company B (a 
furniture manufacturer). Both programs were considered successful with improved employee attitudes, better firm performance, suggestions, and increased levels of trust in management.

\section{Quantitative Studies}

A total of four publications using multiple cases fall into this category. Doherty, Nord, and McAdams (1989) reviewed corporate records at four firms using organizational change interventions, where gainsharing was one of the methods used. The results indicate that gainsharing led to improved productivity and quality, lower costs, improved safety, better attendance, and an enhanced awareness of the corporations' goals. They concluded that gainsharing and organization development complement each other.

Wallace (1990) published the results of a three year study focusing on alternative pay systems where he researched a total of 46 organizations to understand their experiences with a variety of reward systems including gainsharing. He found that approximately $46 \%$ of the firms sampled relied on some form of gainsharing and that gainsharing and skill-based pay were the most commonly used alternative reward plans. Frequently the gainsharing formulas were being tailored to fit a firm's strategy rather than adhering to the old Scanlon plan procedures. For example, the formula used often included a variety of criteria not traditionally considered to be components of bonus calculations (e.g., customer service, quality). In addition, gainsharing plans were being extended to include non-production employees, and they were being implemented in industries that had previously been unfamiliar with these programs (i.e., health care, financial institutions, and retailing). In summary, Wallace found an increased interest in gainsharing, creative approaches toward implementation of these plans, and favorable responses from firms that had instituted the programs.

Hatcher, Ross, and Collins (1991) interviewed 149 supervisors and non-management employees in five gainsharing companies. The data was codified by inductively classifying comments into categories. The authors report that: (a) affective organizational commitment and trust are important prerequisites for the gainsharing plan to succeed; (b) specific mechanisms to provide recognition for the individual employees who get involved should be in place; and (c) employees take into account whether or not management is acting in good faith before being committed to the plan.

The last article in this category, by McGrath (1994), provides an overview of the gainsharing programs at Huron Automatic Screw Company, Milan Screw Products Company, and EPCO Products. All three of these programs heavily emphasized employee participation. According to McGrath, based on his unstructured interviews with managers and employees, 
gainsharing in these firms led to greater "teamwork, efficiency, quality, employee satisfaction, and company profits ... and lower turnover rates and costs" (p. 446) .

\section{Descriptive Field Studies - Single Cases}

A total of 45 cases describe the experiences of a single firm that implemented gainsharing. Thirty three of these cases use a narrative approach, while 12 rely on some type of quantitative measure (see right hand side of Exhibit 5). The qualitative and quantitative single case studies are discussed in turn.

\section{Qualitative Studies}

The 33 case studies falling under this category are listed in Exhibit 8, with the author, firm name, and a brief summary of the gainsharing plan results. As can be seen by browsing Exhibit 8, reported results are predominantly positive. Although most of these publications involve manufacturing firms, there are examples of other industries such as restaurants and hospitals (Jewell \& Jewell, 1987; Davidson, 1988; Finney, 1989) and government operations (Naff \& Pomerleau, 1988; Gilbert \& Nelson, 1989). The earliest case study reported was published in Life magazine by Chamberlain (1946) detailing the experience of Adamson Company; this article is later cited by management and union officials at LaPointe Machine Tool Company as the impetus for their considering gainsharing. LaPointe was the subject of several later case studies (Davenport, 1950; Daigneault, 1952; Dowd, 1955). As can be seen in Exhibit 8 , most of the earlier reported cases were Scanlon plans, while the later cases tended to be customized gainsharing programs, most of which were tailored after the Scanlon Plan and include the involvement system (e.g., Owens, 1991; Peck, 1991 a,b). Schodlatz (1955) published information on the Rucker Plan with results similar to those obtained by Scanlon plans, including increased profits and bonuses averaging $13.5 \%$. 


\section{EXHIBIT 8}

\section{QUALITATIVE LITERATURE - SINGLE CASE STUDIES}

SP = Scanlon plan

CGS = Customized gainsharing plan

\begin{tabular}{|c|c|c|}
\hline Author & Company Name & Results \\
\hline Chamberlain (1946) & Adamson Co. & SP - Positive \\
\hline $\begin{array}{l}\text { Davenport (1950) } \\
\text { Daigenault (1952) } \\
\text { Dowd (1955) }\end{array}$ & $\begin{array}{l}\text { LaPointe Machine } \\
\text { Tool Co. }\end{array}$ & SP - Positive \\
\hline Schodlatz (1955) & Reznor Mgt. Co. & $\begin{array}{l}\text { Rucker plan } \\
\text { Positive }\end{array}$ \\
\hline Martucci (1957) & Pfaudler Co. & SP - Positive \\
\hline Gilson \& Lefcowitz (1957) & New Jersey Ceramics Co. & SP - Unsuccessful \\
\hline Jehring (1967) & $\begin{array}{l}\text { Mgt. Co. - Household } \\
\text { Fixtures }\end{array}$ & SP - Positive \\
\hline $\begin{array}{l}\text { Moore (1976) } \\
\text { Cummings \& Molloy } \\
\text { (1977) }\end{array}$ & Desoto, Inc. & SP - Positive \\
\hline Ewing (1977) & Donnelly Mirros, Inc. & SP - Positive \\
\hline Schulhof (1979) & Rocky Mtn. Data Systems & SP - Positive \\
\hline Ramquist (1982) & Herman Miller & SP - Positive \\
\hline Hatcher \& Ross (1986) & Peabody Galion (mfg. firm) & CGS - Positive \\
\hline Yarbrough (1987) & $\begin{array}{l}\text { American Valve \& Hydrant } \\
\text { Co. }\end{array}$ & SP - Positive \\
\hline $\begin{array}{l}\text { Hauck \& Ross (1987) } \\
\text { Hauck \& Ross (1988) }\end{array}$ & Volvo & CGS - Positive \\
\hline Magnus (1987) & $\begin{array}{l}\text { Vulvan Materials Co. } \\
\text { (construction) }\end{array}$ & CGS - Positive \\
\hline Jewell \& Jewell (1987) & Restaurant & CGS - Positive \\
\hline Ross \& Collins (1987) & $\begin{array}{l}\text { Tech Forms } \\
\text { Industries }\end{array}$ & CGS - Positive \\
\hline $\begin{array}{l}\text { Hatcher, Ross \& Ross } \\
\text { (1987) }\end{array}$ & Dana Spicer & CGS - Positive \\
\hline Owens (1988) & Mosier Industries & CGS - Positive \\
\hline Davidson (1988) & Southern Co. Services & CGS - No results reported \\
\hline Naff \& Pomerleau (1988) & $\begin{array}{l}\text { Office of Federal } \\
\text { Investigations }\end{array}$ & CGS - Mixed \\
\hline Finney (1989) & Hospital & CGS - Positive \\
\hline Gilbert \& Nelson (1989) & McClellan Air Force Base & CGS - No results \\
\hline Anonymous (1989) & Huffy Corporation & CGS - Positive \\
\hline Woods (1989) & Naval Aviation & CGS - Some Positive \\
\hline $\begin{array}{l}\text { Ross, Hatcher \& Ross } \\
\text { (1989) }\end{array}$ & Tech Form Industries & CGS - Positive \\
\hline Florkowski (1990) & $\begin{array}{l}\text { Unionized co. in auto } \\
\text { industry }\end{array}$ & $\begin{array}{l}\text { "What if" discussion, no } \\
\text { results }\end{array}$ \\
\hline Owens (1991) & Mosier Industries & CGS - Positive \\
\hline Peck $(1991 a, b)$ & $\begin{array}{l}\text { Lower Valley Power \& } \\
\text { Light }\end{array}$ & CGS - Positive \\
\hline Kissler (1992) & Manufacturing facility & CGS - Positive \\
\hline
\end{tabular}


Many of the earlier Scanlon plans were installed in an effort to find a substitute for piece-rate systems that were not living up to expectations (Dowd, 1955; Schodlatz, 1955; Ramquist, 1982; Ross, Hatcher \& Ross, 1987). These employers found that their piece-rate systems resulted in a variety of problems including: poor quality, work group problems associated with "rate busters", fears that employees would lose their jobs if they excel the standard, sophisticated responses by employees designed to "beat the system" when time studies were being conducted, high maintenance costs associated with administration of the plans, and generally poor labor relations climates. In contrast, gainsharing plans were believed to increase profits (Chamberlain, 1946; Jehring, 1967; Schulhof, 1979; Moore, 1976; Yarbrough, 1987), enhance labor management relations (Daigenault, 1952; Dowd,1955), improve quality (Ramquist, 1982; Hatcher, Ross \& Ross, 1987) and reduce turnover rates (Hauck \& Ross, 1987; Yarbrough, 1987).

The only two articles that reported negative results tended to cushion the findings by advancing reasons why the plans had less than optimal outcomes. Gilson and Lefcowitz (1957) blamed poor results on the nature of the work force, characterizing employees as housewives who did not wish to participate on the job; they also noted defects in the general operation of the Scanlon plan as reasons for the lack of success. Naff and Pomerleau (1988) also reported an unsuccessful plan that was installed in the Office of Federal Investigations Division in San Francisco. Although it was labeled as gainsharing, it was administered in a fashion very similar to that used in a piece-rate system; therefore, it did not encompass many of the expected characteristics of gainsharing.

In summary, this literature primarily reports the positive results accruing to individual firms that installed gainsharing. These publications lack substantial data or statistical analysis. Interviews with the CEO, managers, employees, and union representatives are common and tend to be portrayed in narrative form. These qualitative studies provide impressionistic information on the types of environments most favorable to gainsharing and outcomes that might be expected given certain program characteristics. However, results are difficult to compare and generalize because of their firm specificity and lack of sufficient detail.

\section{Quantitative Studies}

A total of 12 single case studies used empirical measures to depict gainsharing results (see last column of Exhibit 5). These studies tend to be very similar to the qualitative single case studies in terms of their goal, which is providing descriptive information about a particular firm's experience with gainsharing. 
Gray (1971) reported the results of an unsuccessful attempt to install gainsharing at the Linwood plant of Pressed Steel Company. Data reported include numbers of suggestions between 1963 and 1964, departmental analysis of suggestions, absenteeism, overtime, lost time, and strike information. This study is one of a few that have failed to show positive gainsharing outcomes. This was primarily blamed on poor implementation.

Ross and Jones (1972) reviewed employee responses to a complex gainsharing formula at a anonymous firm to examine whether employee knowledge of the bonus computation was related to length of service, suggestions submitted, and number of times elected to a committee. The results indicated that length of service and knowledge were correlated (.416); in addition, significant correlations were found between knowledge and number of suggestions submitted (.238), number of times elected to a committee (.347), and hierarchical level in the organization (.384).

Schultz and McKersie (1973) studied an oil company to determine if gainsharing might be feasible at three work sites. The study involved collection of interview and archival data to determine how the system might work; the article then lists suggestions regarding the conditions under which gainsharing might be successful.

DeBettignies (1987) conducted a study of communication patterns within a firm that had implemented gainsharing. The data that resulted from studying 131 employees' attitudes toward communication patterns indicated significant positive changes in attitudes toward lateral communication, but no changes in upward or downward communication patterns were discovered.

Banker and Datar (1987) conducted a field study at a division of a Fortune 500 company and found that accounting problems existed in their gainsharing formula. Their analysis, which included extensive interviews with managers and reviews of corporate records, indicated a better measurement for labor productivity might be useful. They proceed to detail the new measurement system, when and why it might be more appropriate, and the advantages associated with its use.

Miller and Schuster (1987) employed an interrupted time series design with data that spanned over a nine year period of time to determine the results of gainsharing installation at a large, manufacturing firm. They found moderate and consistent productivity improvement and bonus payment in addition to a total of 5,000 suggestions being submitted during that period of time.

Gowen and Jennings (1990) examined productivity changes of 179 employees of a unionized manufacturing plant that implemented gainsharing. Because the plan was changed 
from non-participative to participative during the study, the authors were able to compare in a longitudinal fashion productivity figures under both conditions. Gowen and Jennings (1990: 162) concluded that "[the] study demonstrates the highly significant improvement in employee productivity and scrap rate cost savings in a gainsharing program which was changed from a non-participative to a participative plan."

Flannery and Williams (1990:61) describe the positive results accrued by the University of Alabama Hospital in Birmingham after implementing a customized form of gainsharing. According to the author "patients are happier, productivity has improved, and the hospital has increased its margin by fourfold in the first year alone. The second year financial results are eight times better than they were at the start of the program. "

Masternak (1993) and Masternak and Ross (1992) examined the results of gainsharing programs introduced at BF Goodrich and two facilities of a chemical firm in Austin and Dallas. In all cases the authors found dramatic improvements in quality, costs, and employee attitudes. The authors attribute gainsharing success to greater employee involvement, open communications, and perceived fairness of the gainsharing formula used.

More recently, Hanlon, Meyer and Taylor (1994) studied a gainsharing program in a large package delivery firm. A unique twist to this study is that at some point during the plan the bonuses were eliminated yet the participation mechanisms remained. The authors report large attitudinal improvements as a result of gainsharing. Three months after the bonus was eliminated, attitudinal measures remained positive. Hanlon et al (1994: 107) draw the following policy implications from their study: "In light of this research it may indeed be appropriate to eliminate the group bonus at a mutually agreed upon point. Managers do not have to be so concerned with designing a bonus formula that will generate infinite savings, gains/bonuses, which would seem to be a formidable goal."

The single case studies provide a considerable amount of information regarding the results of specific gainsharing programs; the data indicates that interest in gainsharing is on the rise and many organizational benefits are associated with it. The conclusions from these studies are similar to those derived by reviewing the qualitative studies - that gainsharing can be successfully implemented in a wide variety of settings.

Unfortunately, the case study literature is not balanced in term of reporting both successful and unsuccessful attempts at gainsharing; it is not clear whether gainsharing plans are actually successful in the majority of cases or if unsuccessful cases are simply not published. Most firms retain the right to the publication of sensitive materials; gainsharing results are not likely to be divulged unless management believes it can reap a public relations benefit 
by doing so (i.e., by portraying a predominately successful story). An objective, critical analysis is almost totally absent from this literature so it is difficult to ascertain those factors that mediate the relative effectiveness of these programs.

\section{Surveys}

We identified a total of 19 exploratory surveys in the gainsharing literature (see Exhibit 6). There is no doubt that additional surveys have been and are being conducted by private consulting firms or other organizations. Although most surveys may never be published, this representative group of studies should sufficiently cover this domain.

The majority of surveys report the frequency of gainsharing use. In addition, many publications include data regarding the reasons such plans are introduced and information describing the results of gainsharing implementation. Often the authors design questionnaires that are not focused primarily on gainsharing, but gainsharing data are embedded in inquiries regarding such topics as involvement programs (Lawler, Ledford \& Mohrman, 1989), workplace innovations (Long, 1989), union-management cooperation methods (Voos, 1987), and incentive programs (Nickel, 1990; Lawler \& Cohen, 1992). In addition to the studies that aim to uncover the frequency of gainsharing use and the results of such programs, four surveys focus on more specific research questions. These two sets of studies are discussed in turn.

\section{Frequency and results oriented surveys.}

In one of the earliest studies, Goodman, Wakeley \& Ruh (1972) conducted a survey of 21 Scanlon plan sites, giving questionnaires to a total of 2,636 employees. Goodman et al. were interested in employee evaluations of gainsharing and found that as a whole employees' reactions were rather positive. The United States General Accounting Office (USGAO) published two studies on gainsharing $(1981,1986)$. The first study $(1981)$ conducted a survey of 38 firms (names of organizations were obtained from consultants) with gainsharing plans (17 had Scanlon plans, 8 Rucker, 11 Improshare, and 2 other) and uncovered very favorable outcomes, including improved labor-management relations (reported by $80.6 \%$ of the organizations), reduced number of grievances (47.2\%), and less absenteeism and turnover $(36.1 \%)$. The later study (1986) focused on efforts made by the Department of Defense to implement gainsharing; USGAO conducted extensive interviews and reviewed documents in 16 installations that had introduced gainsharing. The study indicated that all gainsharing plans resulted in cost savings (ranging from $\$ 7,000$ to $\$ 1$ million); some locations also reported decreases in sick time and overtime. Freund and Epstein (1984) published the results of a New York Stock Exchange survey covering 49,000 corporations with 100 or more employees. Their study was designed to discover the frequency in use of innovative human resource 
management systems. They found that $15 \%$ of approximately 7,000 firms with 500 or more employees had some form of gainsharing; of those, $61 \%$ to $77 \%$ said that gainsharing resulted in improved firm performance. Their definitions of gainsharing, however, included profit sharing as a form of gainsharing.

Voos (1987) sent questionnaires to 379 managers in Wisconsin firms and requested data pertaining to labor relations programs implemented by these organizations. It was found that 62 had installed either gainsharing or profit sharing plans, and 18 of these had discontinued such systems. Additional details regarding the managers perceptions of these plans are included in the summary statistics.

O'Dell and McAdams (1987) conducted a survey of the members of the American Productivity Center and the American Compensation Association to determine the frequency with which a variety of human resource management systems, including gainsharing, were used. They concluded that the results indicated a growth in "non-traditional" reward systems. A total of 211 firms (13\%) had installed gainsharing (their definition does not include profit sharing as a form of gainsharing). Their data led them to state that "gainsharing plans are the fastest growing of all the non-traditional pay-for-performance plans" (p. 34), and they also noted that this trend was expected to continue.

Lawler, Ledford \& Mohrman (1989) accessed a sub-sample of a 1987 USGAO job involvement strategies surveys and concluded from their report that merit pay continues to be the dominant method of paying for performance within the United States. They also noted that $26 \%$ of the sample had some form of gainsharing, but in most instances only a small percentage of the workforce was covered under such system. A follow up survey by Lawler and Cohen (1992) reported a large increase in the use of gainsharing, with 39\% of Fortune 100 firms relying on some form of gainsharing program.

Long (1989) conducted a study of Canadian firms using workplace innovations; the questionnaires were sent to 5,000 organizations. The results indicated that $9.7 \%$ of these businesses used some form of gainsharing, while approximately $25 \%$ had profit sharing plans installed. They also noted that $70 \%$ of the gainsharing plans had been introduced in the past six years.

Ost (1990) surveyed 102 U.S. firms by telephone and mail regarding the types of pay for performance plans that were in use. A total of 30 out of 102 firms (29\%) had some form of gainsharing, and four additional organizations indicated they planned to add gainsharing. Nickel (1990) published the results of a Towers Perrin study that surveyed Fortune 100 and smaller firms in Fall of 1989. A sample of 212 firms responded to a follow-up survey focusing on 
group incentives; the results indicated that $33 \%$ had gainsharing plans while $37 \%$ had profit sharing; a total of $30 \%$ of the firms had some blended form of profit sharing and gainsharing. Markham, Scott and Little (1992) surveyed 10,000 human resources professionals from the Society for Human Resource Management (SHRM). Based on a response of 1,639 members, Markham et al. found that gainsharing is found in all industrial sectors but it is clearly more common in manufacturing. Their data indicates that customized plans are far more popular than all of the traditional "off the shelf" programs combined (i.e., Scanlon, Improshare, and Rucker). A similar survey of SHRM members by the Alexander Consulting Group (1992) found that gainsharing was perceived as a critical issue this decade, outranking other contemporary issues such as work force diversity and corporate culture.

A more focused gainsharing survey consisting of Improshare users by Kaufman (1992) report that the median productivity increase was about $8 \%$ in the first year, and the cumulative productivity gains had risen to $17.5 \%$ by the 3rd year. After the 3rd year productivity gains begin to level off. Respondents indicate that most of the gains reflect reductions in downtime and defect rates. An interesting aspect of this survey is that significant improvements are attributed to gainsharing even though employee participation plays a relatively minor role in the population surveyed (i.e., Improshare users).

Lastly, the Wyatt Data Services (1995) reports that $11.6 \%$ of firms use gainsharing for technical and skilled trades. Gainsharing effectiveness for these groups was rated higher than the effectiveness of annual bonuses, spot awards, small group incentives, profit sharing, and individual incentives.

In summary, the surveys reviewed above all seem to be indicative that gainsharing is a popular reward system and that its use is on the rise. Consistent with the case studies reviewed earlier, results are generally very positive as reported by survey participants. The same caveats apply here, however, in that companies with failing or disappointing gainsharing programs may be less likely to complete the survey. Unfortunately we don't know to what extent this response bias may distort the survey results. In addition, interpretation of much of this data remains an open question. For instance, Goodman et al. (1972) attribute their positive findings to greater employee participation under Scanlon. Kaufman (1992), on the other hand, attributes his positive findings to the bonus system under Improshare and appears to de-emphasize the role of employee participation.

\section{Focused surveys}

White (1979) surveyed a total of 23 companies to gather data with the intention of determining the types of factors that led to gainsharing plan success, where success was 
specifically defined as plan retention. White concluded that plan retention was related to attitudes toward participative decision making, number of years the plan was in place, the expected level of success, and the attitudes of the CEO and top management team.

Hauck (1981) conducted a survey that focused on comparing the formulas used in the Scanlon, Rucker, and Improshare systems. Executives at two hospitals and seven banks were surveyed to determine if industry-type was a determinant of formula appropriateness. The results indicated that industry was not as important as labor intensity, and it was noted that labor intensive firms preferred a Scanlon-type formula. This is not surprising since Scanlon plans are designed to reduce labor costs. In a subsequent study, Hauck (1986) sent out a survey inquiring whether hospitals or banks preferred the single or multi-cost ratios; the results seemed to indicate that industry again was not a determinant of formula preference.

Hatcher and Ross (1986) surveyed managers at firms with gainsharing plans to determine the perceived level of influence managers exercised while working in a gainsharing environment. Their survey indicated that managers perceived they had a considerable amount of influence while gainsharing was in operation. For example, $75 \%$ indicated their ability to "get the job done" was good or very good after gainsharing compared to only $64 \%$ prior to gainsharing.

In summary, these four studies are also favorably predisposed toward gainsharing. In addition to the caveats discussed above concerning other surveys, a potential problem here is that if asked people are more likely to attribute failure to external factors and success to internal factors. There is also a strong cultural bias against mentioning money as an important issue even when deep down it is often foremost in people's minds (Gomez-Mejia \& Balkin, 1992a). Thus one needs to be somewhat skeptical of self-reports indicating why gainsharing works or doesn't work and expressed preferences by individuals completing the survey.

\section{RESEARCH AGENDA FOR THE FUTURE}

Throughout the article we have identified methodological or conceptual weaknesses in the gainsharing literature that should be addressed in future research. Two issues in particular stand out. First, there is a dire need for more theory based studies. Gainsharing as an area of research is no longer at an exploratory stage. As we saw earlier, hundreds of studies have been conducted on gainsharing yet only a handful of these test formal propositions derived from a conceptual framework. Many such hypotheses, as summarized in Exhibit 1, are readily available to guide future empirical work. Second, new methodologies are required that provide for a stronger test of causation. Reliance on self-report indicators where all measures are obtained from the same respondent should be especially discouraged. Use of multiple sources of data for 
independent and dependent variables (e.g., managers, employees, customers, personnel files) would tend to mitigate artifactual results prompted by social desirability, attribution biases, and common method variance (all of which plague much of the empirical work on gainsharing). Whenever possible, longitudinal rather than cross-sectional studies should be conducted. This last section of the manuscript raises specific research questions on gainsharing that provide interesting leads for future studies.

\section{Linking aggregate, team, and individual rewards}

One of the criticisms of gainsharing programs is that they are prone to free-riding because the performance criteria used to distribute rewards encompasses collective contributions but not individual inputs. In a highly individualistic culture such as that of the U.S. this form of aggregate incentive is likely to be demotivating and perhaps lead to opportunistic behaviors (e.g., shirking) because a person's relative contribution is neglected in the bonus allocation (Gomez-Mejia \& Welbourne, 1991). It is possible, however, that this problem may be minimized under certain conditions. First, as noted in the introduction, a growing number of firms are differentially allocating the gainsharing proceeds (which are generated via an aggregate performance formula) to teams and individuals based on relative contributions to the "common good." Second, many firms utilize multiple layers of rewards simultaneously so that the disadvantages of one plan may be neutralized by the advantages of another. For instance, merit pay and key contributor bonuses recognize individual contributions, yet engender competition. Gainsharing, if used alongside these programs, can promote cooperation even though it may not increase individual motivation.

Research that focuses on how the organizational advantages of gainsharing may be accrued while at the same time recognizing individual contributions is almost nil. This is important for obvious practical reasons because ultimately the success of any gainsharing program depends on employees' willingness to make a personal commitment to it. This is also important from a theoretical perspective. For instance, one can envision a conceptual framework to study this issue that links individual based motivation models (such as expectancy theory) with group based models (such as participative management) and organizational level models (such as contingency theory).

\section{Gainsharing as a control mechanism}

Some have suggested that gainsharing reduces the need for hierarchical organizational structures because it creates an incentive alignment system that in effect substitutes direct monitoring by supervisors with mutual monitoring by peers (Kandel \& Lazear, 1992; Welbourne et al., in press). In other words, by linking rewards to common interests, agents have a stake in 
the contributions of their peers and as a consequence engage in monitoring those with whom they are cooperatively linked. This means that the individuals involved play a dual role: They act as principals in monitoring others, but also serve in the role of agent to the same people they are monitoring.

Unfortunately, we know little as to how much mutual monitoring actually occurs under gainsharing plans. Future research can benefit by behaviorally measuring mutual monitoring patterns, the effect this has on supervisors, and how group dynamics may engender or thwart the intensity and direction of such monitoring. For instance, it is conceivable that a negatively perceived gainsharing program may increase mutual monitoring in a manner prejudicial to the organization (e.g., holding back more efficient ways to perform the job if participants are afraid of layoffs). We also know little as to how much of the observed mutual monitoring, if any, is attributed to a greater social awareness of each other (committee participation) or to the potential magnitude of the bonus (incentive alignment).

\section{Gainsharing as an instrument of change}

A number of firms implement gainsharing in an effort to modify or redirect the organization's culture (Gomez-Mejia \& Balkin, 1992a). A common objective is to use gainsharing to create a shared sense of corporate mission and to rally workers behind this mission., through greater employee involvement and aggregate performance contingent bonuses. It is often believed that gainsharing can move an organization from a climate of distrust, adversarial relations, and internal conflict to one that is more open, supportive, and cohesive.

Little is known, however, as to how gainsharing may be successfully used as a change agent and the conditions that lead to favorable results. In particular, from a contingency perspective, it is important to understand how other elements of the system may need to change concurrently for gainsharing to be effective (e.g., work design, organizational structures). It is also possible that some specific forms of gainsharing may be better change agents under some conditions than others. For example, an Improshare type program may be more appropriate for a situation with a poor labor relations climate because it demands less employee involvement. Alternatively, it could be argued that a Scanlon type plan that requires extensive employee participation may offer the greatest benefits for firms that have a dysfunctional conflict ridden culture because it forces people to discuss and solve their differences in the open instead of letting these problems fester behind closed doors.

In short, while many case studies have examined factors associated with gainsharing success, more theoretical and empirical work is necessary to learn the conditions under which 
these plans may be effectively implemented as change agents, and how specific elements of these plans (e.g., degree of participation) are more or less suitable to these varying conditions.

\section{Understanding failures}

As noted earlier, almost all gainsharing case studies are successful stories or tend to gloss over potential problem areas. A practical reason for this is that management is not likely to open the door to investigators to interview workers and publish potentially embarrassing information, particularly if a labor union is involved. Thus, only positive gainsharing results tend to see the light of day. Yet, by some estimates up to two-thirds of gainsharing plans do not meet expectations (Imberman, 1993). There is far more to learn if future case studies were to focus on failure, rather than favorable situations. This would bring greater balance to the present gainsharing literature that takes a strong advocacy role. On the flipped side, it can also offer more insights as to why gainsharing succeeds. Some of these failed attempts are well known (such as the case of Dupont in the early 1990's) yet very little systematic investigation and analysis of these situations can be found anywhere. Admittedly this is going to be a difficult task given managerial reluctance to open up, but there may be ways to circumvent this fear (such as guaranteeing anonymity to a given company while providing it with access to information from other firms that are also kept anonymous). One way to start would be to identify those firms which have dropped their gainsharing programs in the recent past and target these for in-depth examination.

\section{Gainsharing as a strategic tool}

Much has been said in recent years about the need to design compensation systems to support corporate and business unit strategies (see Gerhart and Milkovich, 1993 for a review of this literature). The bulk of the empirical research on these issues is concentrated on top management pay and general characteristics of the reward system for exempt employees (e.g., emphasis on variable versus fixed pay, degree of centralization in pay decisions). To the authors' knowledge none of the empirical studies have examined how the strategic objectives of the firm link with gainsharing, and their joint effect on firm performance.

There is ample reason to suspect that these relationships are important as noted by GomezMejia and Balkin (1992a) using Miles and Snow's (1978) strategy typology. Firms pursuing a prospector or growth strategy may need to proceed cautiously when introducing gainsharing programs because bonuses are tied to productivity increases above base productivity measures. A stable history will help assure a fair bonus distribution and make the calculation of the bonus better understood by employees. Unstable or scanty data based on historical records will make it difficult to establish reliable future performance standards. If the 
firm is constantly changing the bonus calculations, confidence in the system is likely to suffer. By the same token, prospectors and growth firms need a greater degree of flexibility. Gainsharing may contribute to firm performance by increasing the proportion of variable pay allowing the company to better respond to environmental jolts.

\section{Risk and behavioral response to gainsharing}

All gainsharing programs involve some degree of economic risk to employees because the bonus is uncertain. Few firms actually reduce salary or merit raises when the aggregate performance outcomes fall below a certain level. Most, however, infuse risk by making it difficult to reach performance goals and/or by allocating fewer resources to increases in fixed income (e.g., merit pay which becomes part of base salary) in exchange for offering employees the potential to earn a higher reward (i.e., a bonus). Employees respond to perceived risk in future unsecured income by being more or less conservative in work related decisions that they believe affect that future income. The key decision employees exert some control on in a gainsharing program concerns the generation and assessment of suggestions. These suggestions may vary in the amount of risk involved. For instance, the resources required to implement the suggestion, the technological and work flow changes associated with the suggestion, uncertainty in mean-end relationships and the like all affect the relative risk of decisions made under the auspices of the gainsharing program.

Little is known about the factors that influence the degree to which gainsharing participants are risk averse or risk seeking. This is an important issue because too much risk aversity may mean that good ideas or innovations with the potential for high productivity returns or significant savings are discouraged. On the other hand, too much risk seeking may induce embracing suggestions with a low probability of success and a high cost of failure.

Future research can focus on this issue from several angles. First, the type of performance measure used by the gainsharing plan may play an important role in the risk posture adopted by employees. The risk literature suggests that decision makers are risk averse to the point of selecting less desirable options when faced with situations where they exercise very limited influence on outcomes (MacCrimmon \& Wehrung, 1986; 1990). Gainsharing programs utilize a variety of formulas with varying levels of employee control over the outcomes or criteria used to trigger the award. The greatest degree of control is afforded by plans which rely on productivity measures because workers can influence efficiency and cost structure. The lowest degree of control exists in gainsharing plans where bonuses are linked to broader criteria of firm performance such as profitability or market value because these are more sensitive to external events that may have little to do with how efficiently a firm is run. 
Second, it is possible that the relationship between risk shifting to employees (e.g., if a high proportion of take home pay is in the form of a non-recurrent bonus), and the benefits derived from gainsharing is curvilinear (Welbourne \& Gomez-Mejia, 1995). That is, up to a certain point collective risk is beneficial to the organization because of greater consonance of interest between employees and the firm and the incentive to engage in mutual monitoring. After a certain point, however, too much risk sharing in a group incentive program is likely to be dysfunctional. For instance, increased productivity or efficiency may be perceived as detrimental to job security as more risk is shifted to employees. It is possible that employees will rebel by using mutual monitoring to increase job security as much as possible within their own work teams. Such a situation has been well documented with piece-rate systems whenever workers felt these threatened their jobs (Gomez-Mejia \& Balkin, 19928).

Third, prospect theory would predict that the performance context facing the firm may influence the employee's risk aversity in a gainsharing program. Individuals facing a loss context tend to be more risk seeking than those facing a gain context (Kahneman \& Tversky, 1979). This suggests that to the extent a gainsharing program is introduced "to turn things around" (a loss context) it would trigger a risk seeking response. Conversely, if a gainsharing program is implemented to "make a good situation better" (a gain context), then it is more likely to evoke a risk averse response.

Fourth, the more collective risks are shifted to employees under a group incentive program, the more salient the perceived fairness of the program becomes to the risk posture adopted by employees. By definition making riskier decisions involves a greater possibility of loss. The perceived negative consequences of failure and associated insecurities augment when fairness is low. This induces the group to become more cautious in decision making for fear of retaliation, whether real or imagined. At the opposite end, positive justice perceptions allow individuals to see risk more as an opportunity than a threat, and therefore this increases their willingness to trade off risk against potential high returns where the benefits of alternative options increase with their risk. In other words, lack of perceived fairness increases the perception of loss, the significance of those losses, and the uncertainty associated with those losses. Therefore, this condition fuels the insecurity of workers (e.g., fear that greater cost savings will lead to layoffs), which in turn triggers a self-protection reaction leading to increases risk aversion.

In summary, risk represents a key construct that may affect the effectiveness of gainsharing and that can enhance our behavioral understanding of how employees respond to 
these programs. The literature on risk is extensive (see review by Yates, 1992) and can provide a solid foundation for future research on these issues.

\section{Multidimensional reward criteria}

The traditional gainsharing programs described earlier (Scanlon, Rucker, \& Improshare) use efficiency as the criterion to calculate the bonus pool. Efficiency is generally assessed in terms of labor or material cost savings relative to a historical base. The primary justification for relying on efficiency as a payoff criterion is that employees have direct control over the factors that influence efficiency and therefore could do something about those in order to receive a bonus.

Unlike the traditional efficiency driven plans rooted in the manufacturing sector, custom designed gainsharing programs (which account for a major portion of the recent growth of these aggregate incentives across a broad spectrum of industries) tend to rely on complex payoff formulas idiosyncratic to the firm (Markman et al., 1992). The bonus criteria may include meeting deadlines, quality, customer satisfaction, safety, cooperation with other units, innovation, accounting performance and market share. They may or may not emphasize efficiency (Wallace, 1990).

There is virtually no published scholarly research on how these multifaceted bonus formulas affect employee reactions to gainsharing and their relative success. Many research questions come to mind in this regard. For instance: How do employees cognitively decide which portion of the formula is most important and should be maximized, perhaps at the expense of other elements in the formula? How do employees react to the greater risk inherent in a bonus formula where some of the elements can not be directly controlled? How does the "mix" of the bonus formula affect employee behaviors (e.g., proportion of "controllable" over "less controllable" factors)? What is the behavioral impact of a complex reinforcement schedule with varying targets (i.e., one for each portion of the formula)? How do firms utilize customized formulas to implement their business strategies? How do aggregate multidimensional performance criteria modify the theoretical predictions discussed earlier (in terms of participation, expectancies, agency costs, social dilemmas and the like)? Answers to questions such as these are important given that greater firm flexibility in designing the incentive properties of the reward formula is a major impetus for the increased adoption of gainsharing, particularly outside the manufacturing sector (Gomez-Mejia \& Balkin, 1992a). 


\section{Committee decision making}

Despite all the emphasis on interpersonal processes in the participative management research reviewed earlier, little is known about how the composition of gainsharing committees influence decisions concerning the generation, evaluation, and implementation of suggestions. There is a growing body of knowledge on organizational demography and cultural diversity that may be brought to bear on these issues (e.g., Wiersema \& Bird, 1993; Watson, Kumar, \& Michaelsen, 1993; Tsui, Egan, \& O'Reilly, III, 1992). This literature suggests that group membership affects team outcomes such as productivity and creativity of solutions.

As organizations become increasingly heterogeneous in terms of ethnicity, age, race, gender and the like, the effectiveness of participative gainsharing programs may depend in part on how team members are assigned. For instance, some have argued that greater intragroup diversity stimulates flexibility, change, innovation and comprehensive decision making, all of which enhance the performance of the team (Cox, 1991). One could therefore hypothesize that diverse gainsharing committees should exercise more ingenuity in coming up with new ideas and make better decisions when choosing among alternative options. On the other hand, it is possible that less diverse groups are "more likely to have a stronger culture with shared values, terminology, and belief structures [which] facilitate communication, problem solving, and fast decision-making" (Glick, Miller, \& Huber, 1993: 176).

Which of the two scenarios noted in the preceding paragraph is better or worse in terms of gainsharing outcomes may depend on the environmental context and committee stability. An empirical study by Glick et al. (1993) found that employee diversity makes a greater contribution to performance in turbulent environments, such as those encountered by many high technology firms. Watson et al. (1993) reports that for long standing committees greater heterogeneity leads to better group outcomes. However, for short term, transient teams less diversity produces better results because less time is required for members to adapt to each other. In any case, the whole area of group decision making processes provide fertile grounds for future research on gainsharing. For those interested in these types of issues existing gainsharing programs provide a natural laboratory for hypothesis testing. 


\section{References}

Alexander Consulting Group (1992). Health care costs, quality top list of human resources concerns. Employee Benefit Plan Review, 47(3), 38-39.

Anonymous (1989). Racing to win on costs. Journal of Business Strategy, 10 (2), 4-8.

Arrow, K. J. (1985). The economics of agency. In J. W. Pratt \& R. J. Zeckhauser (Eds.), Principals and agents: The structure of business (pp. 37-51). Cambridge, MA: Harvard Business School Press.

Atkinson, J. W. (1958). Motives in fantasy, action, and society. Princeton, New Jersey: Van Nostrand.

Bailey, T. (1993). Discretionary effort and the organization of work: Employee participation and work reform since Hawthorne. Unpublished manuscript. Teachers college, Columbia University.

Banker, R. D. \& Datar, S. M. (1987). Accounting for labor productivity in manufacturing operations: an application. In W. J. Bruns, Jr. \& R. S. Kaplan (Eds.) Accounting and management: Field study perspectives (pp. 169 - 201). Boston, Massachusetts: Harvard Business School.

Barney, J. \& Ouchi, W. (Eds.). (1986). Organizational economics. San Francisco, CA: Jossey-Bass.

Beck, D. (1992). Implementing a gainsharing plan: What companies need to know. Compensation \& Benefits Review, 24(1), 21-33.

Bowman, E. (1980). A risk/return paradox for strategic management. Sloan Management Review, 21(3), 17-31.

Bowman, E. (1982). Risk seeking by troubled firms. Sloan Management Review, 23(4), 33-42.

Bullock, R. J. \& Bullock, P. F. (1982). Gainsharing and Rubik's cube: solving system problems. National Productivity Review, 396-407.

Bullock, R. J. \& Lawler, E. E. (1984). Gainsharing: A few questions and fewer answers. Human Resource Management, 23 (1), 23-40.

Bullock, R. J. \& Tubbs, M. E. (1990). A case meta-analysis of gainsharing plans as organization development interventions. The Journal of Applied Behavioral Science, 26, 383-404.

Bureau of National Affairs Special Report (1988). Changing pay practices: New developments in employee compensation. Washington, D.C.: The Bureau of National Affairs, Inc.

Burtnett, G. (1973). A study of causal relationships between organization variables and personal influence during implementation of a Scanlon plan. Ph.D. dissertation, Michigan State University. 
Cardy, R.L., \& Dobbins, G. (1993). Performance appraisal. Cincinnati, OH: South-Western Publishing Co.

Chamberlain, J. (1946). Every man a capitalist. Life, 12/23/46, pp. 93-94.

Collins, D., Hatcher, L., \& Ross, T. L. (1993). The decision to implement gainsharing: The role of work climate, expected outcomes, and union status. Personnel Psychology, 46, 77-104.

Cooper, C. L., Dyck, B., \& Frohlich, N. (1992). Improving the effectiveness of gainsharing: The role of fairness and participation. Administrative Science Quarterly, 37, 471-490.

Cox, T. (1991). The multicultural organization. Academy of Management Executive, 5(2), 34-47.

Crum, R., Laughhunn, D., \& Payne, J. W. (1980). Risk preference: Empirical evidence and its implications for capital budgeting. In F. G. J. Derkinderen \& R. L. Crum (eds.). Financing issues in corporate project selection, Martinus Nyhoff: Boston, Mass.

Cumming, C. (1995, January). Now is an opportune time to fix merit pay-for-performance plans. ACA News, 11-12.

Cummings, T. G. \& Molloy, E. S. (1977). Improving productivity and the quality of work life. New York: Praeger.

Daigenault, H. (1952). Sharing the profits of increased productivity. Personnel Series No. 147, AMA, 9-16.

Daly, P. H. (1975). Selecting and designing a group incentive plan. Personnel Journal, 54, June, 322-356.

Dar-El, E. M. (1986). Productivity improvement: Employee involvement and gainsharing plans. Amsterdam: Elsevier.

Davenport, R. W. (1950). Enterprise for everyman. Fortune, 41(1), 51-58.

Davidson, R. L. (1988). Gainsharing incentive spurs productivity. Transmission and Distribution, 40(12), December, 42, 44.

Davis, E. C. (1991). Gainsharing: No magic bullet. Employment Relations Today, 18(2), 241-246.

DeBettignies, C. W. (1987). The impact of gainsharing on organizational communication. Dissertation Abstracts International, 48,(4-B), 1176-1177, University of Houston, Texas.

DeBettignies, C. W. (1991). Using gainsharing to improve financial performance. Industrial Management, 33(3), 4-6.

Doherty, E. M., Nord, W. R., \& McAdams, J. L. (1989). Gainsharing and organizational development: A productive synergy. Journal of Applied Behavioral Science, August, 209230.

Dowd, E. M. (1955). The Scanlon Plan. Management Record, 17, 236-239. 
Doyle, R. J. (1970). A new look at the Scanlon Plan. Management Accounting, 52(3), 4852.

Doyle, R. J. (1982). Gainsharing: A total productivity approach. Journal of Contemporary Business, 11(2), 57-70.

Doyle, R. J. (1983). Gainsharing and productivity: A guide to planning implementation and development. New York, NY: AMACOM

Dreher, G. F. (1980). Individual needs as correlates of satisfaction and involvement with a modified Scanlon Plan company. Journal of Vocational Behavior, 17(1), 89-94.

Driscoll, J. W. (1978). Trust and participation in organizational decision making as predictors of satisfaction. Academy of Management Journal, 21, 44-56.

Dulworth, M. R. \& Ucilaner, B. L. (1987). Federal government gainsharing systems in an environment of retrenchment. National Productivity Review, 6(2), 144-152.

Dyl, E. A. (1988). Corporate control and management compensation: Evidence on the agency problem. Managerial and Decision Economics 9(1), 21-25.

Eisenhardt, K. M. (1985). Organizational control: Organizational and economic approaches. Management Science, 31, 134-149.

Ewing, J. C. (1989). Gainsharing plans: Two key factors. Compensation and Benefits Review, January/February, 49-53.

Fama, E. F. \& Jensen, M. L. (1983). Separation of ownership and control. Journal of Law and Economics, 26, 301-325.

Fiegenbaum, A. \& Thomas, H. (1986). Dynamic and risk measurement perspectives on Boman's risk-return paradox for strategic management: An empirical study. Strategic Management Journal, 7(5), 395-408.

Fiegenbaum, A. \& Thomas, H. (1988). Attitudes toward risk and the risk-return paradox: Prospect theory explanations. Academy of Management Journal, 31(1), 85-106.

Fein, M. (1991). Improshare: A technique for sharing productivity gains with employees. In Rock, M. L. \& Berger, L. A. (Eds.), The Compensation Handbook, 3rd edition. (pp. 158-175). New York: McGraw-Hill, Inc.

Finney, M. 1. (1989). Planning today for the future's changing shape. Personnel Administrator, 34(1), 44-49.

Fishburn, A. \& Kochenberger, G. A. (1975). Two piece Von Neumann Morgensten Utility Functions. Decision Science, 27, 25-39.

Flannery, T. P. \& Williams, J. B. (1990). The shape of things to come: Part 3 - inspiring peak performance. Healthcare Forum, 33(5), 56-63.

Florkowski, G. W. (1990). Analyzing group incentive plans. Human Resource Magazine, 35(1), 36-38. 
Florkowski, G. W. \& Lifton, D. E. (1987). Assessing public sector productivity incentives: A review. Public Productivity Review, 43, Fall, 53-70.

Folger, R., \& Konovsky, M. (1989). Effects of procedural and distributive justices on reactions to pay raise decisions. Academy of Management Journal, 32, 115-130.

Freud, W. C. \& Epstein, E. (1984). People and productivity: The New York Stock Exchange guide to financial incentives and the quality of work life. Homewood, IL: DowJones.

Irwin. Frost, C. (1978). The Scanlon Plan: Anyone for free enterprise? Michigan State University Business Topics, 26(1), 25-33.

Frost, C., Wakeley, J. \& Ruh, R. (1974). The Scanlon plan for organization development: Identity, participation, and equity. East Lansing, MI: Michigan State University Press.

Geare, A. J. (1976). Productivity from Scanlon-type plans. Academy of Management Review, 99-108.

Gerhart, B., \& Milkovich, G.T. (1993). Employee compensation: Research and practice. In M.D. Dunnette \& L.M. Hough (Eds.), Handbook of Industrial and Organizational Psychology (Vo1.3). Palo Alto, CA: Consulting Psychologists Press, Inc.

Gilbert, G. R. \& Nelson, A. E. (1989). The Pacer Share demonstration project: Implications for organizational management and performance evaluation. Public Personnel Management, 18(2), Summer, 209-225.

Gilson, T. \& Lefcowitz, M. (1957). A plant-wide bonus in a small factory: Study of an unsuccessful case. Industrial and Labor Relations Review, 10(2), 284-296.

Glick, W.H., Miller, C.C., \& Huber, G.P. (1993). Organizational change and redesign: Ideas and insights for improving performance. New York: Oxford University Press.

Gomez-Mejia (1988J. Evaluating employee performance: Does the appraisal instrument make a difference? Journal of Organizational Behavior Management, 9(2), 155-170.

Gomez-Mejia, L. R. (1994). Executive compensation: A reassessment and a future research agenda. In Ferris, G. (Ed.). Research in Personnel and Human Resources Management, $12,161-222$.

Gomez-Mejia, L. R., \& Balkin, D. B. (1992b). The determinants of faculty pay: An agency theory perspective. Academy of Management Journal, 35(5), 921-955.

Gomez-Mejia, L. R. \& Balkin, D. B. (1992J. Compensation, organizational strategy, and firm performance. Cincinnati, Ohio: South Western Publishing Co.

Gomez-Mejia, L .R., Balkin, D. B. \& Cardy, R. L. (1995). Managing Human Resources. Englewood Cliffs, NJ: Prentice-Hall.

Gomez-Mejia, L .R. \& Welbourne, T. M. (1991). Compensation strategy in a global context. Human Resource Planning, 14(1), 29-42. 
Goodman, P. \& Moore, B. E. (1976). Factors affecting acquisition of beliefs about a reward system. Human Relations, 29(6), 571-588.

Goodman, R. K., Wakeley, J. H. \& Ruh, R. H. (1972). What employees think of the Scanlon plan. Personnel, September/October, 22-29.

Gowen, C. R., 111. (1990). Gainsharing programs: An overview of history and research. Journal of Organizational Behavior Management, 11, 77-99.

Gowen, C. R., III. \& Jennings, S. A. (1990). The effects of changes in participation and group size on gainsharing success: A case study. Journal of Organizational Behavior Management, 11, 147-169.

Graham-Moore, B. E. \& Ross, T. L. (1983). Productivity gainsharing: How employee incentive programs can improve business performance. Englewood Cliffs, NJ: PrenticeHall, Inc.

Graham-Moore, B. E. \& Ross, T. L. (1990). Gainsharing: Plans for improving performance. Washington, D.C.: The Bureau of National Affairs.

Gray, R. B. (1971). The Scanlon Plan: A case study. British Journal of Industrial Relations, 9 , 291-313.

Greenwood, W. (1977). The Scanlon plan profile: Construct validation and test of a model of Scanlon plan effectiveness. Ph.D. dissertation, Michigan State University.

Gross, S. \& Bacher, J. P. (1993). The new variable pay programs: How some succeed, why some don't. Compensation and Benefits Review, 25(1), 51-56.

Hackman, J. R. \& Suttle, J. L. (Eds.) (1977). Improving life at work: Behavioral science approaches to organizational change. Santa Monica, CA: Goodyear.

Hammer, T. (1988). New developments in profit sharing. In J. Campbell, R. Campbell, \& Associates, Productivity in Organizations. San Francisco, CA: Jossey-Bass.

Hammerstone, J. E. (1987). How to make gainsharing pay off. Training and Development Journal, 41(4), 80-81.

Hanlon, S. C. \& Meyer, D. G. (1992). Reversal of a successful gainsharing program: Experimental evidence of residual effects. Paper presented at the Academy of Management Meeting, Las Vegas, NV.

Hanlon, S. C., \& Taylor, R. R. (1991). An examination of changes in work group communication behaviors following installation of a gainsharing plan. Group \& Organization Studies, 16, 238-267.

Hanlon, S. C., Meyer, D. G., \& Taylor, R. R. (1994). Consequences of gainsharing: A field experiment revisited. Group \& Organization Management, 19, 87-111.

Harrington, J. H. \& Harrington, J. S. (1995). Total improvement management: The next generation in performance improvement. New York, NY: McGraw-Hill, Inc. 
Hatcher, L., Ross, T. L. \& Collins, B. (1989). Prosocial behavior, job complexity, and suggestion contribution under gainsharing plans. Journal of Applied Behavioral Science, 25(3), 231-248.

Hatcher, L. \& Ross, T. L. (1983). Organization development through productivity gainsharing. Personnel, October, 42-50.

Hatcher, L. \& Ross, T. L. (1986). Gainsharing plans: How managers evaluate them. Business, 36(4), 30-37.

Hatcher, L., Ross, T. L. \& Collins, D. (1991). Attributions for participation and nonparticipation in Gainsharing-plan involvement systems. Group \& Organization Studies, 16, 25-43.

Hatcher, L., Ross, T. L. \& Ross, R. A. (1987). Gainsharing: Living up to its name. Personnel Administrator, 32(6), 154-164.

Hauck, W. C. (1981). An evaluation of alternative productivity gainsharing formulas for use in service sector industries. Dissertation Abstracts International, 42, AAD81-18799, Case Western Reserve.

Hauck, W. C. (1986). Measuring effectiveness in banks and hospitals with productivity gainsharing formulas. Industrial Management, 28, March-April, 26-27.

Hauck, W. C. (1987). Productivity improvement at branch banks. National Productivity Review, 6(3), 243-249.

Hauck, W. C. \& Ross, T. L. (1987). Sweden's experiments in productivity gainsharing: A second look. Personnel, 64(1), 61-67.

Hauck, W. C. \& Ross, T. L. (1988). Expanded teamwork at Volvo through performance gainsharing. Industrial Management, 30, July/August, 17-20.

Holstrom, B. (1979). Moral hazard and observability. Bell Journal of Economics, 10, 7491.

Hughes, C. L. (1986). The demerit of merit. Personnel Administrator, 31(6), 40.

Ichniowski, C., Shaw, K. \& Prennushi, G. (1994). The effects of human resource management practices on productivity. Unpublished manuscript, Graduate School of Business, Columbia University.

Ilgen, D. R., \& Feldman, J. M. (1983). Performance appraisal: A process focus. In L. L. Cummings \& B. M. Staw (Eds.), Research in Organizational Behavior. Greenwich, CT: JAI Press.

Imberman, W. (1992). Boosting plant performance with gainsharing. Business Horizons, 35(6), 77-79.

Imberman, W. (1993). Gaining performance, sharing productivity. Manufacturing Systems, 11(4), 54-56. 
Jehring, J. J. (1967). A contrast between two approaches to total systems incentives. $\underline{\text { California }}$ Management Review, 10, Winter, 7-14.

Jensen, M. C. \& Meckling, W. H. (1976). Theory of the firm: Managerial behavior, agency costs, and ownership structure. Journal of Financial Economics, 3, 305-360.

Jewell, D. O. \& Jewell, S. F. (1987). An example of economic gainsharing in the restaurant industry. National Productivity Review, 6(2), 134-143.

Johnson, S. T. (1993). What's ahead in work design and rewards management. Compensation \& Benefits Review, 25(2), 35-41.

Kahneman, D. \& Tversky, A. (1979). Prospect theory: An analysis of decisions under risk. Econometrica, 47: 262-291.

Kandel, E. \& Lazear, E. P. 1992. Peer pressure and partnership. Journal of Political Economy, 100(4), 801-817.

Kaufman, R. T., (1992). The effects of IMPROSHARE on productivity. Industrial \& Labor Relations Review, 45, 311-322.

Kissler, G.D. (1992). Interview appearing in Employee Benefit Plan Review, 46(8), 47-48.

Kochan, T., \& Dyer, L. (1976). A model of organizational change in the context of unionmanagement relations. Journal of Applied Behavioral Science, 12, 59-78.

Kotowitz, Y. (1989). Moral hazard. In J. Eatwell, M. Milgate, \& P. Newman (Eds.), The new palgrave: Allocation, information, and markets. (pp. 207-213).

Krulee, G. K. (1955). The Scanlon Plan: Cooperation through participation. The Journal of Business, 28(2), 100-113.

Lane, H. E. (1975/76). The Scanlon Plan revisited. Business and Society, 16, 57-64.

Laughhunn, D. J., Payne, J. W. \& Crum, R. (1980), Managerial risk preferences for below target returns. Management Science, 26(12), 1238-1249.

Lawler, E. E., III. (1981). Pay and organization development, Reading, Mass. AddisonWesley.

Lawler, E. E., III. (1986). High involvement management. San Francisco: Jossey-Bass.

Lawler, E. E., III. (1988). Gainsharing theory and research: Findings and future research directions. Research in organizational change and development, 2, 323-344.

Lawler, E. E., III. (1990). Strategic pay. San Francisco: Jossey Bass.

Lawler, E. E. III. (1992). Effective reward systems: Strategy, diagnosis, design, and change. CEO Publication G 93-5 (225).

Lawler, E. E., III \& Cohen, S. G. (1992). Designing a pay system for teams. American Compensation Association Journal, 1(1), 6-19. 
Lawler, E. E.,111, Ledford, G. E. \& Mohrman, S. A. (1989). Employee involvement in America. Houston, TX: American Productivity and Quality Center.

Lesieur, F. G. (Ed.) (1958). The Scanlon Plan - A frontier in labor-management cooperation. Cambridge, MA: MIT Press.

Lesieur, F. G. (1959). Worker participation to increase production. Management record, 21(2), 38-41.

Lesieur, F. G., \& Puckett, E. S. (1968). The Scanlon plan: Post, present, future. Proceedings of the Twenty-first Annual meeting of the Industrial Relations Research Association.

Lesieur, F. G. \& Puckett, E. S. (1969). The Scanlon Plan has proved itself. Harvard Business

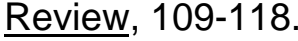

Lewin, K. (1947). Frontiers in group dynamics: Concept, method, and reality in social science, social equilibria and social change. Human Relations, 1, 5-41.

Liden R. C., \& Mitchell, T.R. (1983). The effects of group interdependence on supervisor performance evaluations. Personnel Psychology, 36, 289-299.

Long, R. J. (1989). Patterns of workplace innovation in Canada. Industrial Relations, 44, 805-824.

Lowin, A. (1968). Participative decision making: A model, literature critique, and prescription for research. Organizational Behavior and Human Performance, 3, 68-106.

MacCrimmon, K. R., \& Wehrung, D. C. (1986). Taking risks: The management of uncertainty. New York: The Free Press.

MacCrimmon, K. R., \& Wehrung, D. C. (1990). Characteristics of risk taking executives. Management Science, 36, 422-435.

MacDuffie, J. P. (1994). Human resource bundles and manufacturing performance: Flexible production systems in the world auto industry. Unpublished manuscript, Wharton School, University of Pennsylvania.

Magnus, M. (1987). Personnel policies in partnership with profit. Personnel Journal, 66(9), 102-109.

Manz, C. C. \& Sims, H. P., Jr. (1993). Business without bosses. New York: Wiley.

Markham, S. E. \& Scott, K. D. (1988). A new job for the 90's (productivity gainsharing coordinator). Personnel Administrator, 33(8), 36-40.

Markham, S. E., Scott, K. D. \& Little, B. L. (1992). National gainsharing study: The importance of industry differences. Compensation \& Benefits Review, 24(1), 34-35.

Markowich, M. M. (1993). Does money motivate? HR Focus, 70(8), 1-6.

Martucci, N. (1957). Productivity and incentive pay. Management Record, 19(10), 346349. 
Masternak, R. L. (1992). Gainsharing boosts quality and productivity at a B. F. Goodrich plant. National Productivity Review, 1202, 225-238.

Masternak, R. L. (1991-1992). Gainsharing programs at two Fortune 500 facilities: Why one worked better. National Productivity Review, 11(1), 71-86.

Masternak, R. L. (1993/94). Gainsharing: Overcoming common myths and problems to achieve dramatic results. Employment Relations Today, 20(4), 425-446.

Masternak, R. L. \& Ross, T. L. (1992). Gainsharing: A bonus plan or employee involvement? Compensation \& Benefits Review, 2404, 46-54.

Mawhinney, T. C. \& Gowen, C. R. 111. Gainsharing and the law of effect as the matching law: A theoretical framework. Journal of Organizational Behavior Management, 11, 61-75.

Mayo, E. (1945). Social problems of an industrial society. Andover, MA: The Andover Press.

McClelland, D. C., Atkinson, J. W., Clark, R. A. \& Lowell, E. L. (1953). The achievement motive. New York: Appleton-Century-Crofts.

McGrath, T. C. (1994). How three screw machine companies are tapping human productivity through gainsharing. Employment Relations Today, 20(4), 437-447.

McGregor, D. (1960). The human side of enterprise. New York: McGraw-Hill.

Metzger, B. L. (1985). Participative gainsharing. Evanston, IL: Profit Sharing Research Foundation.

Miles, R. \& Snow, C. (1978). Organizational strategy: Structure and process. New York: McGraw-Hill.

Milkovich, G. T. (1987). Gainsharing in managing compensation and human resources. Working paper \#87-03. Center for advanced Human Resource Studies, Cornell University, Ithaca, NY.

Milkovich, G. \& Milkovich, C. (1992). Strengthening the pay-performance relationship: The research. Compensation \& Benefits Review, 24(6), 53-62.

Miller, C. S., \& Schuster, M. H. (1987). Gainsharing plans: A comparative analysis. Organizational Dynamics, 16(1), 44-67.

Moore, B. E. (1976). The Scanlon plant-wide incentive plan: A case study. Training and Development Journal, February, 50-53.

Moore, B. E. (1982). Sharing the gains of productivity. Work in America Institute Studies in Productivity \#24. New York: Pergamon Press.

Moore, B. E. \& Goodman, P. S. (1972). Organizational learning: The relation of antecedent variables to job expectancies. In Proceedings of the 80th Annual Convention, American Psychological Association. 
Mount, M. K. (1987). Coordinating salary action and performance appraisal. In: D. B. Balkin \& L. R. Gomez-Mejia (Eds.), New perspectives on compensation. Englewood Cliffs, MJ: Prentice Hall, Inc.

Murray, H. A. (1938). Explorations in personality. New York: Oxford University Press.

Musselwhite, W. C. (1988). Knowledge, pay, and performance. Training and Development Journal, 42(1), 62-65.

Naff, K. C. \& Pomerleau, R. (1988). Productivity gainsharing: A federal sector case study. Public Personnel Management, 17(4), 403-419.

National Center for Productivity and Quality in Working Life (1976). Recent Initiatives in Labor-Management Cooperation, 1, February, 43-50.

National Center for Productivity and Quality in Working Life (1978). Recent Initiatives in Labor-Management Cooperation, 2, Spring, 5-12.

Nickel, J. E. (1990). Can your organization achieve better results by sharing gains with employees? Employment Relations Today, 17, 173-184.

O'Dell, C. S. (1981). Gainsharing: Involvement, incentives, and productivity. New York, NY: AMACOM

O'Dell, C. S. \& McAdams, J. (1987). People, performance, and pay: A national survey of non-traditional reward practices. Houston, TX: APC.

O'Neill, D. (1994). Blending the best of profit sharing and gainsharing. HR Magazine, March, 66-70.

Ost, E. J. (1990). Team-based pay: new wave strategic incentives. Sloan Management Review, Spring, 19-27.

Owens, T. (1988). Making gainsharing work. Small Business Reports, 13(10), 29-32.

Owens, T. (1991). Gaining from gainsharing. Small Business Reports, 16(8), 51-60.

Paulsen, K. M. (1991). Lessons learned from gainsharing. HRM Magazine, 36(4), 70-74.

Payne, J. W., Laughhunn, D. J., \& Crum, R., (1980). Translation of gambles and aspiration level effects in risky choice behavior. Management Science, 26(10), 1039-1060.

Payne, J. W., Laughhunn, D. J., \& Crum, R., (1981). Further tests of aspiration level effects in risky choice behavior. Management Science, 26(10), 1039-1060.

Pearce, J. L., Stevenson, W. B., \& Perry, J. L. (1985). Management compensation based on organizational performance: A time-series analysis of the impact of merit pay. Academy of Management Journal, 28, 261-279.

Peck, C. A. (1991J. Gainsharing for Productivity. New York: New York. 
Peck, R. G. (1991b). Gainsharing - a compensation idea that is long past due. Management Quarterly, 32(1), 25-30.

Peterson, R. B. \& Tracy, L. (1988). Lessons from labor-management cooperation. California Management Review, 31(1), 40-53.

Puto, C. P. (1987). The framing of buying decisions. Journal of Consumer Research. December, 353-364.

Ramquist, J. (1982). Labor-management cooperation: The Scanlon Plan at work. Sloan Management Review, 23(3), 49-55.

Rock, M. L. \& Berger, L. A. (1991). The Compensation Handbook, 3rd edition. (pp. 158175). New York: McGraw-Hill, Inc.

Ross, T. L. \& Collins, D. (1987). Employee involvement and the perils of democracy: Are management's fears warranted? National Productivity Review, 6(4), 348-359.

Ross, T. L. \& Hatcher, L. (1993). Gainsharing drives quality improvement. Personnel Journal, 71(,11), 81-89.

Ross, T. L., Hatcher, L, \& Ross, R. A. (1987). Training for performance gainsharing. Training and Development Journal, 41(11), 65-67.

Ross, T. L., Hatcher, L. \& Ross, R. A. (1989). The incentive switch: From piecework to company-wide gainsharing. Management Review, 78(5), 22-26.

Ross, T. L. \& Hauck, W. C. (1983). Productivity gainsharing: Way of the future or current fad? Operations Management Review, Summer.

Ross, T. L. \& Jones, G. (1972). An approach to increased productivity: The Scanlon Plan. Financial Executive, 40(2), 23-29.

Ross, T. L. \& Ross, R. A. (1984). Productivity gainsharing: Resolving some of the measurement issues. National Productivity Review, 3(4), 382-394.

Ruh, R., Johnson, R. H., \& Scontrino, M. P. (1973). The Scanlon plan - Participation in decision making and job attitudes. Journal of Industrial and Organizational Psychology, 1, 36-45.

Ruh, R., Wallace, R., \& Frost, C. (1973). Management attitudes and the Scanlon plan. Industrial Relations, 12, 282-288.

Ruh, R. A., White, J. \& Wood, R. R. (1975). Job involvement, values, personal background, participation in decision making, and job attitudes. Academy of Management Journal, 18(2), 300-312.

Scarp, M. J. (1995, February). Texas Instrument aligns compensation plans to each division's business strategy. ACA News, 5-6.

Schodlatz, W. C. (1955). The Rucker share of productivity plan. Management Record, 17, 239-240. 
Schulhof, R. J. (1979). Five years with a Scanlon plan. The Personnel Administrator, June, 55-62;92.

Schultz, G. P. (1951). Worker participation on production problems: A discussion of experience with the "Scanlon Plan". Personnel, 28, 201-211.

Schultz, G. P. \& McKersie, R. B. (1973). Participation-achievement-reward systems. Journal of Management Studies, 10(2), 141-161.

Schuster, M. (1983). Forty years of Scanlon Plan research. In C. Crouch \& F. Heller (Eds.), International yearbook of organizational democracy, 1, 53-72. Chichester, England: Wiley.

Schuster, M. (1984a). The Scanlon Plan: A longitudinal analysis. Journal of Applied Behavioral Science, 20(1), 23-38.

Schuster, M. (1984b). Union-management cooperation: Structure, process, and impact. Kalamazoo, MI: The W. F. Upjohn Institute.

Schuster, M. (1985). Models of cooperation and change in union settings. Industrial Relations, 24(3), 382-394.

Schuster, M. \& Miller, C. S. (1987). Gainsharing: A productivity tool. Quality Circle's Journal, 10(3), 24-28.

Pay-Performance relationships as a function of pay-for-performance policies and practices. Proceedings of the Academy of Management, Los Angeles, 287-290.

Schwab, D. P., \& Olson, C. A. (1990). Merit pay practices: Implications for pay-performance relationships. Industrial and Labor Relations Review, 43(1), 237-255.

Scott, R. C. (1988). Test your gainsharing potential. Personnel Journal, May, 82-84.

Shavell, S. (1979). Risk sharing and incentives in the principal and agent relationship. Bell Journal of Economics, 10, 55-73.

Sims \& Manz 1993.

Singh, H. \& Montgomery, C. A. (1987). Corporate acquisition strategies and economic performance. Strategic Management Journal, 8(4), 363-377.

Sitkin, S. B., \& Pablo, A. L. (1992). Reconceptualizing the determinants of risk behavior. Academy of Management Review, 17, 9-38.

Smith, E. \& Gude, G. (1971). Reevaluation of the Scanlon plan as a motivational technique. Personnel Journal, 50, May, 916-923.

Stiglitz, J. E. (1989). Principal and agent. In J. Eatwell, M. Milgate, \& P. Newman (Eds.), The new palgrave: Allocation, information, and markets. (pp. 241-253). 
Strauss, G. \& Sayles, L. R. (1957). The Scanlon Plan: Some organizational problems. Human Organization, Fall, 15-21.

Thomas, B. W. \& Olson, M. H. (1988). Gainsharing: The design guarantees success. Personnel Journal, 67, May, 73-82.

Thompson, C. (1993). A penny saved. Credit Union Management, 14(4), 46-49.

Thor, G. G. (1987). Employee involvement and productivity gainsharing. Industrial Management, July/August, 21-24.

Tosi, H. L. \& Gomez-Mejia, L. R. (1994). CEO monitoring: A behavioral approach. Academy of Management Journal.

Tsui, A.S., Egan, T.D., \& O'Reilly, III, C.A. (1992). Being different: Organizational demography and organizational attachment. Administrative Science Quarterly, 37, 549-579.

U.S. General Accounting Office (1981). Productivity gainsharing programs: Can they contribute to productivity improvements? Washington: GAO, March 31.

U.S. General Accounting Office (1986). Gainsharing: DOD efforts highlight an effective tool for enhancing federal productivity: Briefing report to the Chairman-Subchairman on Defense Committee on Appropriation, House of Representatives.

Voos, P. B. (1987). Managerial perceptions of the economic impact of labor relations. Industrial and Labor Relations Review, 40(2), 195-208.

Wallace, M. (1990). Rewards and renewal: America's search for competitive advantage through alternative pay strategies. Scottsdale, AZ: American Compensation Association.

Wallace, R. L. (1971). A comparative study of attitude scores of managers toward employees and toward selected leadership policies in groups of firms which either discontinued or retained cost reduction sharing plans. Unpublished doctoral dissertation, Industrial Relations Center, University of Minnesota.

Watson, W. E., Kumar, K., \& Michaelsen, L.K. (1993). Cultural diversity's impact on interaction process and performance. Academy of Management Journal, 36(3), 590-602.

Welbourne, T. M., Balkin, D. B. \& Gomez-Mejia, L. R. (in press). Gainsharing and mutual monitoring. Academy of Management Journal.

Welbourne, T. M. \& Gomez-Mejia, L. R. (1988). Gainsharing revisited. Compensation and Benefits Review, 20(4), 19-28.

Welbourne, T. M. \& Gomez-Mejia, L. R. (1995). The effect of aggregate incentives on employee behavior. Agency theory and prospect theory perspectives. Working paper. School of Industrial and Labor Relations, Cornell University.

White, J. K. (1979). The Scanlon Plan: Causes and correlates of success. Academy of Management Journal, 22(2), 292-312. 
White, J. K. \& Ruh, R. A. (1973). The effect of personal values on the relationship between participation and job attitudes. Administrative Science Quarterly, 18(4), 506-514.

Whyte, W. (1955). Money and motivation: An analysis of incentives in industry. New York: Harper \& Row.

Wiersema, M., \& Bird, A. (1993). Organizational demography in Japanese firms: Group heterogeneity, individual dissimilarity, and top management team turnover. Academy of Management Journal, 36(5), 996-1025.

Wilson, T. B. (1992). Is it time to eliminate the piece rate incentive system? Compensation and Benefits Review, 24(2), 43-49.

Woods, M. D. (1989). Gainsharing in industry. Journal of Accountancy, 167, 143-146.

Wyatt Data Services /ECS (1995, January). Many technicians and skilled workers receive variable pay. CompFlash, 3.

Yammarino, F. J., Dubinsky, A. J., \& Hartley, S. W. (1987). An approach for assessing individual versus group effects in performance evaluations. Journal of Occupational Psychology, 60, 157-167.

Yarbrough, J. (1987). The benefits of gainsharing. Small Business Report, 12(4), 90.

Yates, J. F. (1992). Risk-taking Behavior. New York: John Wiley and Sons, Ltd.

Zajac, E. J. (1990). CEO selection, succession, compensation, and firm performance: A theoretical integration and empirical analysis. Strategic Management Journal, 11(3), 217-230. 